\title{
SÜRGÜNDEN SONRA HAYBER YAHUDILERI
}

\section{NUH ARSLANTAŞ*}

Medine'nin kuzeyinde yer alan Hayber, Yahudilerin Arabistan'da yaşamaya başladıkları en eski yerleşim yerlerinden biriydi. İslam kaynaklarında Hayber kelimesinin İbrânîce "kale" anlamına geldiği belirtilir'. Cahiliye döneminde şehirde yedisi büyük, irili ufaklı kalelerin bulunduğu göz önüne alınırsa bu anlamlandırma oldukça isabetlidir ${ }^{2}$. Charles Torrey, Hayber adının İbrânîce'de "cemaat", "topluluk" anlamına gelen "hever" (חבר) kelimesinin Arapçalaşmış şekli olduğunu belirtir".

Hayber Yahudilerinin şehirdeki kökeni çok eskiye dayanmaktadır. Yahudi seyyah Benjamin, Hayber Yahudilerinin Ruben, Gad, Manasse kabilelerinin soyundan geldiğini ve Asur Kralı Salmaneser zamanında buraya sürüldüklerini söyler' ${ }^{4}$. Yahudi araşturmacılardan H. Graetz ve R. Dozy, Hayber Yahudileri'nin Buhtunnasr zamanında gelip şehre yerleştikleri kanaatindedirler. Ancak bunlar Hayber Yahudilerinin ataları hususunda ihtilaf etmektedir. Graetz, Hayber Yahudilerinin atalarının Tevrat'ta zikri geçen (II. Krallar 10/5) Rehav oğlu Yehonadav; Dozy ise Tevrat'ta bahsedilen (Nehemya 11/7) Mahallel oğlu Şefatya olduğunu iddia etmektedir ki ${ }^{5}$, bu bilgi İslâm kaynaklarına da girmiştir. Bekrî, Hayber şehrinin kurucusu-

•Dr., Marmara Üniversitesi, İlahiyat Fakültesi, Islam Tarihi Anabilim Dahı Araşırma Görevlisi.

'Yakût, Mu'cemü'l-Büldân, Beyrut [t.y.], II, 409; Firûzabâdî, el-Megânimü'l-Mütâbe fi Meâlimi Tâbe, nşr. Hamed Câsir, Riyad 1969, s. 135; Kalkaşendî, Subhü'l-A'şâ fi Smâatill-İnşâ, nşr. Muhammed Hüseyin Şemseddin, Beyrut 1987, IV, 295; Eyüp Sabri Paşa, Mir'âtül-Haremeyn, Bahriye Matbaası: Konstantiniye (İstanbul), 1887/1304, II, 1222.

${ }^{2}$ Yâkût, Mu'cem, II, 409; Firûzâbâdî, el-Megânimü'l-Mütâbe, s. 135. Hayber'in meşhur kaleleri şunlardı: Nâim, Kamûs (Ebü'l-Hukayk'a aitti), Şıkk, Netât, Sclâlim, Vatîh ve Ketîbe.

${ }^{3}$ Charles Cutler Torrey, The Jewish Foundation of Islam, New York 1933, s. 13.

‘ Benjamin, Tudelal Benjamin \& Ratisbonlu Petachia Ortaçağ'da İki Yahudi Seyyahm Avrupa, Asya ve Afrika Gözlemleri, trc. Nuh Arslantaş, İstanbul 2001, s. 72. Benjamin'in bu ifadesi Yeşu $18 / 7 \mathrm{vd}$. ile irtibatlandirilmaktadır.

${ }^{5} \mathrm{H}$. Gractz, History of the Jews, The Jewish Publication Socicty of America: 1891, III, 55; R. Dozy, Mekka, s. 136'dan naklen, Cevâd Ali, el-Mufassal fî Târihi'l-Arab kable'l-İlâm, Bcyrut 19761978 , VI, 525-526. 
nu Hayber b. Kâniye b. Mehlâil isimli biri olarak verir ${ }^{6}$. Graetz, Hayber Yahudilerinin Musa'nın (a.s) kayınpederi Yetro'nun (İslam kaynaklarında Şuayb -a.s-) soyundan gelen Rehabîler olduğunu; Dozy ise Hayberlilerin Davud'un (a.s) atası olan Perets soyundan geldiğini iddia etmektedir. Bunlardan ilki tam anlamı ile İsrailoğulları'ndan kabul edilmezken, ikincisi Yahuda'ya nispet edilen bir soydur ${ }^{7}$. Geç dönemlere ait bir Yahudi kroniğinde de Hayber Yahudilerinin Rehabîlerin soyundan geldiği belirtilmiştir.

Benjamin'in ifadesinden hareketle Yahudilerin Hayber'e ilk olarak Asur sürgünüyle geldiği, daha sonra da Babil sürgününden kaçan Yahudilerin buradaki akrabalarına sığındıklanı ve burada müstakil bir cemaat (Hever/Hayber) oluşturdukları anlaşılmaktadır.

Hayber'le ilgili en eski tarihi bilgilere son Babil kralı Nebonid'in (M.Ö. 556-539) 1956 yılında Harran'da bulunan bir yazıtunda rastlanmaktadır. Söz konusu yazıtta adı geçen kralın Teymâ'da ikinci başşehrini kurduktan sonra Hayber'den Medîne'ye geçtiği belirtilmektedir ${ }^{9}$. Bu sırada şehir sakinleri muhtemelen Yahudi olmalıdır. Zira M.Ö. VI. asırda Hayber'de önemli bir Yahudi ticaret kolonisi olduğu bilinmektedir ${ }^{10}$.

\section{Sürgüne Kadar Hayber'de Yahudiler}

Cahiliye döneminde Hayber, kalelerinin sağlamlı̆̆ı, yerleşik bulunduğu vadinin verimliliği ve su bentlerinin çokluğuyla şöhret bulmuştu. Hayber'de her yll hac mevsiminden sonra 10-30 Muharrem tarihleri arasinda Netât panayırı kurulurdu. Şehir ayrıca Arabistan yarımadasının kuzey-güncy ana güzergâhında olması sebebiyle oldukça da zenginleşmişti ${ }^{11}$.

"Bckrî, Mu'cem Me'sta'cem min Esmâil-Bilâdil-Mevâdi', nşr. Mustafa Sakkâ, Bcyruı 1983, II, 523. Aynı bilgi için bkz. Firûzâbâdî, el-Megânimü'l-Mütâbe, s. 136; Eyüp Sabri Paşa, Mir'âtüllHaremeyn, II, 1222.

7 Tekvin, 39/29); Nehemya, 11/4; Yeremya, 35/8; Isracl Friedlander, "The Jews of Arabia and the Rechabites", Jewish Quarterly Review, New Series 1 (1910-1911), s. 252-53. 97.

${ }^{8}$ Bkz. Sambari, Ditrey Yosef, nşr. Shimon Shtolser, Mahon Ben-Tsivi: Yeruşalayim 1994, s.

9 "Tayma”, EJd (Encyclopedia Judaica), XV, 874; 1 lamiclullah, "I laylser", DIA (Türkiye Diyanet Vakfi Íslâm Ansiklopedisi), XVII, 20.

10 Torrey, s. 13.

"Torrey, 13; Grohmann, "Ilayber", IA, V/I, 386; Hamidullah, "Hayber", DIA, XVII, 20; Abdülazîz b. İbrâhim Ömerî, el-Hiref ve's-Smâ'at fi'l-Hicâz fi Asri'r-Resûl, [y.y.] 1985, s. 164; I lammûd b. Dâvî cl-Kesâmî, Şimâlül-Hicâz, Ciddele 1985, s. 200. 
Cahiliye döneminde Mekkelilerin Hayber Yahudileriyle şok sıkı ilişkileri vardı. Mekkeliler düğün merasimleri için büyük ziyafet tencerelerini, kadınların düğünlerde kullanacakları takı ve süs eşyalarını Hayber Yahudilerinden kiralardı. Hatta bir defasında kiralanan bu mücevherlerden biri kaybolmuş, Mekkeliler Hayberlilere on bin dinar tazminat ödemek zorunda kalmışlard ${ }^{12}$. Hz. Peygamber'in dedesi, zemzem kuyusunun açılmasında karşılaştığı muhalefette kendisini yalnız hissettiğinde, Allah'ın kendisine on oğul verdiği takdirde bunlardan birini kurban edeceği şeklinde bir adakta bulunmuştu. Abdülmuttalib'in yaptığı bu adaktan Hayberli bir kâhinenin yol göstericiliği ile çıkış yolu bulduğu rivayet edilin ${ }^{13}$. İbn Habîb'in (ö. 245) el-Münemmak'ında verdiği bilgiye göre, Resûlullah'ın büyük dedelerinden Hâşim, Hayberli bir Yahudi hanımla evlenmiş ve bu evlilikten de Sayfî ve Ebû Sayfî adlı iki oğlu dünyaya gelmişti. Aynı hanım (önce mi sonra mı olduğunu tarihçinin açıklamadığı) Hâşim'in kardeşi Abdülmuttalib ile de evlenmiş, bundan da Mahrama adlı bir çocuğu dünyaya gelmişti. Mahrama da Dâse adlı Hayberli bir kızla evlenmiş bunların da Kays adlı bir çocukları olmuştu ${ }^{14}$.

Hayber gerek Cahiliye gerekse sonraki dönemlerde humması ile meşhur olmuştu ${ }^{15}$. Ancak Hayberli Yahudiler humma ile yaşamaya alışmışlardı. Kötü iklimine rağmen onlar sağlıklı kalmalarının sırrını şarap içmek, sarımsak yemek, Hayber'in havadar kısımlarında ikamet etmek ve Süreyya takımyıldızının batıp tekrar doğmasına kadar ki sürede Hayber'den uzaklaşmak olarak açıklard $\mathbf{1}^{16}$. Ancak aynı Yahudiler cahil Araplarla eğlenmek için onlara da kendileri gibi sağlıklı olmanın tek yolunun Hayber'e girmeden önce on kere eşek gibi anırmak olduğunu söyler; buna inanan saf bedevîlerin düştüğü o komik durumlarıyla da alay ederlerdi. Câhiliye dönemi

12 Hamidullah, İslam Peygamberi, trc. Salih Tuğ, İstanbul 1990, 1, 591.

13 İbn Hişâm, es-Sîretü'n-Nebeviyye, nşr. Mustafa Sakkâ ve dğr., Beyrut [t.y.], I, 155; İbn Sa'd, et-Tabakâtü'l-Kübrâ, nşr. İhsan Abbas, Bcyrut 1405/1985, I, 88-89.

${ }^{14}$ İbn Habîb, el-Münemmak fí Ahbâri Kureyş, nşr. Hurşid Ahmed Faruk, Beyrut 1985, s. 402403; Hamidullah, İslam Peygamberi, I, 592.

is Câhiz, Kitâbü'l-Hayevân, nşr. Abdüssclam Harun, Bcyrut 1969/1388, IV, 135; İınü'lFakîh, Kîtâbüll-Büldân, nşr. Yûsuf cl-Hâdî, Beyrut 1996, s. 167, 311; Yakût, Mu'cem, IV, 95. 1I\%. Peygamber'in, Medînc'ye hicret edince yeni şehri kendisine scvelirmesi, Hayber humması gilbi herhangi bir hastalığa düçar kılmaması için Allah'a dua ettiği rivayct cdilir. Bkz. a.g.e., III, 315 .

16 İbn Kutcybe, Kitâbül-Envâ, nşr. Muhammed Hamidullah-Charłes Pellat, Frankfurt: Institute for the History of Arabic-Islamic Science at the Johann Wolfgang Gocthe University, 2001, s. 30-31; a.mlf., Uyûnü'l-Ahbâr, nşr. Müfid Muhammed Kumeyha, Bcyrut 1986, III, 292. 
şairlerinden Urve es-Se'alîk ve başka şairlerin eşek gibi anırmak yerine, hummaya tutulmayı yeğlediğine dair bazı şiirleri günümüze ulaşmışıı ${ }^{17}$.

İslamiyet zuhur ettiğinde Arabistan Yahudileri içerisinde en iyi teşkilâtlanmış ve en güçlü Yahudi topluluğu Hayber'de idi ${ }^{18}$.

Hz. Peygamber'in Medine'ye hicretinden sonra Medine Yahudileri gibi Hayber Yahudileri de, yeni dine ve Medine'de kurulan yeni devlete cephe almışlardı. Hatta Mekkeli müşriklerle yaptıkları bir anlaşmaya göre taraflardan birine yapılan saldırı diğerine de yapılmış kabul edilmiş; düşmana karşı müşterek savaşılması kararlaştırılmışı ${ }^{19}$. Diğer taraftan Hayber Yahudileri Medine'den sürülen Nadîroğulları'nın gelmesiyle hem maddî hem de nüfus açısından bir hayli güçlenmişlerdi. Bu dönemden itibaren Hayber, Suriye ve Irak'tan gelip Hayber üzerinden Medine'ye ulaşan kervanlar için tehdit oluşturmaya başlamışı ${ }^{20}$.

Hayber Yahudilerinin yarattığı tehlike bundan ibaret değildi. Onlar ayrıca Mekkeli müşriklerle birlikte Müslümanlara karşı düzenleyecekleri bir saldıı için, dönemin en güçlü kabilelerinden olan Gatafanlılar'a, Hayber'in bir yıllık hurma mahsulünü vaat etmişler ${ }^{21}$; Medine çevresindeki Arap kabilelerini de Medine'ye karşı bir cephede toplamışlardı. Bu ittifakın amacı, Müslümanları Medine'den uzakta savaşa zorlayarak az sayıdaki orduyu tamamen ortadan kaldırmaktı. Hayberlilerin bu faaliyetleri sonucunda Hendek savaşı vuku bulmuş (5/627); ancak savaşta Müslümanların galip gelmesiyle Yahudiler amaçlarına ulaşamamışlardi ${ }^{22}$.

Savaştan sonra Hz. Peygamber Medine için kalıcı bir tehdit haline gelen Yahudileri bertaraf etmek için önce Mekke müşrikleriyle Hudeybiye anlaşmasını yapmış, hatta bu sebeple onların istedikleri şartları kabul etmişti. Hudeybiye, Hayber Yahudilerinin bertaraf edilmesinde bir dönüm noktasıdır. Mekkelilerle Hayberlilerin yukarıda bahsedilen ittifakını kırmaya

${ }^{17}$ Kazvînî, Âsâru'l-bilâd ve Ahbâru'l-ibâd, nşr. Ferdinand Wüstenfeld, Göttingen 1848 [ed. Fuat Sezgin, Frankfurt: Institut für Geschichte der Arabisch-Islamischen Wissenschaften, 1994 (Islamic Geography 198)], II, 60-61; Firûzabâdî, el-Megânimü'l-Mütâbe, s. 136.

${ }^{18}$ Samucl b. Yahya cl-Mağribî, Ifhâmü'l-Yahûd, nşr. Muhammed Abdullah cş-Şcrkâvî, Daru'l-Hidâye 1986, s. 144.

${ }^{19}$ Serahsî, el-Mebsût, Dâru'l-ma'rife: Beyrut 1406, X, 86. 162.

${ }^{20}$ İsrail Velfenson, Târihu'l-Yehûd fi Bilâdi'l-Arab fil'-Câhiliyye ve Sadri'l-Islâm, Mısır 1927, s.

${ }^{21}$ Vakıdî, Kitâbü'l-Meğââi, nşr. Marsden Jones, Beyrut 1965-1966, II, 640.

${ }^{22}$ Velfenson, s. 157; Hamidullah, Hz. Peygamberin Savaşlan, trc. Salih Tuğ, İstanbul 1991, s. 108-109; a.mlf., "Hayber", DIA, XVII, 21. 
yönelik bu anlaşma ile müşriklerin elleri kollan bağlanmış; Müslümanlarla Yahudilerin hesaplaşmalarında tarafsız kalmaları sağlanmıştı. ${ }^{23}$ Hudeybiye' den sonra Hz. Peygamber hicretin yedinci yllında (m. 628) Hayber üzerine yürümüş, yirmi-otuz günlük zorlu bir savaştan sonra şehir fethedilmiştir. Savaşta 93 Yahudi ölürken Müslümanlar da 15 şehit vermişti ${ }^{24}$.

Fetihten sonra Hayber Yahudilerine beklenenin aksine çok sert muamele edilmemiştir. Savaş sonunda onlara Tevrat'a göre muamele edilmiş olsaydı, erkeklerin kılıçtan geçirilip kadın ve çocukların köle yapılması gerekirdi $^{25}$. Ancak Yahudilere kendi kutsal kitaplarındaki bu hüküm uygulanmamışt. Hayberlilerin canlaı bağışlanmış; taşıyabilecekleri mallarla şehri terk etmelerine müsaade edilmişti. Daha sonıa bu karar da yumuşatılarak "Müslümanların istediği bir süreye kadar" yerlerinde kalmaları ve Müslümanlara ait olan topraklarda yetiştirdikleri ürünlerin yarısını alma şartuyla yerlerinde bırakılmışlardı ${ }^{26}$. Hz. Peygamber Hayber topraklarını otuz altı parçaya taksim etmiş, her parçayı da yüz hisseye ayırmıştı. Toprakların yarısı beklenmeyen hadiseler ve olağanüstü ihtiyaçlar için ayırılmış (bunlar el-Ketîbe ve Sülâlim kaleleri idi) diğer yarısı ise Müslümanlar arasında taksim edilmişti $\mathrm{i}^{27}$.

Hayber'in fethi, Arabistan'da büyük bir yankı uyandırmıştır. Yahudilerin savaş gücü, zenginlikleri ve müstahkem kalelerine rağmen mağlup olmalari, Medine aleyhinde faaliyet gösteren müşrik kabilelere gözdağı olmuş;

${ }^{23}$ Velfenson, s. 159; Hamidullah, Hz. Peygamberin Savaşlan, s. 186. Konuyla ilgili değerIendirme için bkz. M. Lecker, "The Hudaybiyya Treaty and the Expedition against Khaybar", Jerusalem Studies in Arabic and Islam 5 (1984), s. 1-11.

${ }^{24}$ Abclürrčzak, el-Musannef, nşr. Habîbürrahman el-'A'zamî, Beyrut 1403/1983, V, 372 (Iladis no: 9738); Belâzurî, Fütâhu'l-Büldân, nşr. Abclullah Enîs et-Tabbâ- Ömer Enîs ctTabbâ, Beyrut 1987, s. 37; Hamidullah, Hz. Peygamberin Savaşlan, s. 191.

${ }^{25}$ Tevrat'ın konuyla ilgili hükmü şudur: ".. Bir şehre cenk etmek için ona yaklaştı̆gn zaman, onu barşsılığa şağıracaksın. Ve vaki olacak $k i$, içinde bulunan büttïn kavm sana angaryact olacaklar, ve sana kulluk edecekler. Ve eğer seninle musalaha etmeyip cenketmek isterse, o zaman onu muhasara edeceksin; ve Allah'in Rab onu senin eline verdiği zaman her erkeğini kulıçtan geçireceksin; ancak kadın, çocuk, hayvan ve bütün mallan kendin için çapul edeceksin..." (T'esniye, 20/10-14). Değerlendirme için bkz. Hamidullah, Islâm Peygamberi, I, 587.

${ }^{26}$ Ebô Yûsuf, Kitâbül'-Harâc, Beyrut [t.y.], s. 50-51; İbn Şcbbe, 1, 177; Bclâzurî, Fütûh, s. 33-34; a.mIf., Ensâbü'l-Eşrâf, nşr. Muhammed Hamidullah, Kahire 1959, 1, 352\%; Mes'ûdî, etTenbîh ve'l-Işrâf, nşr. M. J. Goeje, Leiden 1894 [cd. Fuat Sczgin, Frankfurt: Institut für Geschichte der Arabisch-Islamischen Wissenschaften, 1992 (Islamic Geography 41)], s. 256; Serahsî, el-Mebsût, XXIII, 2; İ̉n Kesîr, el-Bidâye ve'n-Nihâye, Bcyrut 1966, IV, 219 ; İbn Kayyım, Ahkâmu Ehli'z-Zimme, nşr. Subhi Salih, Bcyrut 1983, I, 52.

${ }_{27}$ İbn Sa'd, II, 114; İbn Şebbe, Târîhül-Medîneti'l-Münevvere, nşr. Fehim Muhammed Şcltut, Cidde 1973, I, 181-182; Belâzurî, Fütûh, s. 37. 
onları Müslümanlara karşı tavırlarını gözden geçirmeye sevk etmiştir. Fetihten sonra Müslümanlara düşmanlık besleyen Fedek, Vâdi'l-kurâ ve Teymâ'da yaşayan diğer Yahudi kabileleri de Hz. Peygamber'le anlaşma yoluna gitmiştir ${ }^{28}$.

Hz. Peygamber Hayber'in mahsulleriyle Abdullah b. Revâha'yı görevlendirmişti. İbn Revâha her yıl Hayber'e gider, hurma mahsullerini takdir edip ikiye böldükten sonra Yahudileri istediği bölümü almakta serbest bırakırdı. ${ }^{29}$ Abdullah b. Revâha'nın Mûte savaşında şehit olmasından somra Hayber'e Cebbâr b. Sahr tayin edilmişti ${ }^{30}$. Hayber Yahudileri sürüldüğünde taksimat işi hâlâ Cebbâr b. Sahr tarafından yapılmaktaydı ${ }^{31}$.

\section{Yahudilerin Hayber'den Sürülmesi}

Yahudilerin Hayber'deki ikâmetleri Hz. Ömer dönemine kadar bu şekilde devam etmiştir. Ancak 20/641 yılında Yahudiler Hz. Ömer tarafından Hayber'den sürülmüşlerdir. Hz. Ömer'in Yahudileri sürme gerekçesi olarak kaynaklarda farklı sebepler zikredilmektedir.

Bunlardan ilki Hayber'de baş gösteren bir veba salgınıdır. Belâzurî $\mathrm{Hz}$. Ömer'in Yahudileri veba salgını dolayısıyla sürdüğünü belirtir. Ancak aynı müellif, veba salgını yanında Yahudilerin Müslümanlara çok kötü muamele ettiklerini de kaydeder ${ }^{32}$.

Kaynaklarda Yahudilerin Hayber'den çıkarılmasının bir başka sebebi de ekonomik olarak gösterilmektedir. Hayber'in fethi sırasında geniş ziraat arazilerini işleyecek iş gücüne sahip olmayan Müslümanlar, Hz. Ömer zamanına gelince yeterli iş gücüne (ummâl) sahip olmuşlar, bu sebeple de Yahudilere ihtiyaç kalmamışt ${ }^{33}$.

Sürgünün bir sebebi de fetihten $\mathrm{Hz}$. Ömer'in sürgününe kadar geçen zaman zarfinda Yahudilerin yine tehlike arz etmeğe başlamasıdır. Aslında bu tehlike daha Hz. Peygamber döneminde başlamıştı. Hayber Yahudileri Hz. Peygamberi zehirlemeye teşebbüs etmişler, O'nu olmasa da sahabeden

${ }^{28}$ Bkz. Bclâzurî, Fütûh, s. 41-48; Mes'ûdî, et-Tenbîh ve'l-İ̧̧âf, s. 258.

${ }^{29}$ Aldlürrezzak, el-Musannef, IV, 129 (Hadis no: 7219); Ebû Yûsuf, el-Harâc, s. 51; İbn Şebbe, I, 177-178; Belâzurî, Fütûh, s. 39. Konuyla ilgili diğer rivayetler için bk». Alddürrežak, el-Musannef, IV, 123-126 (I Hadis no: 7203-7210).

${ }^{30}$ Mes'ûdî, et-Tenbîh ve' l-İşrâf, s. 256; İbn Kesîr, IV, 219.

${ }^{31}$ İlon Şcblse, I, 185.

${ }^{32}$ Bclâzurî, Fütûh, s. 34.

${ }^{33}$ Abdürrczzak, el-Musannef, IV, 123 (Hadis no: 7203); a.g.e., V, 372 (Hadis no: 9738); İbn Sa'd, II, 114; İbn Şcblıc, I, 188; Belâzurî, Fütûh, s. 35. 
Bişr b. Berâ'yı şehit etmişlerdi ${ }^{34}$. Yine Peygamberimiz hayatta iken Hayber'e giden Abdullah b. Sehl, fail-i meçhul bir cinayete kurban gitmiş, Hz. Peygamber Hayber Yahudilerinden bu arkadaşının diyetini istemiş; ancak onlar yemin ederek olaydan haberdar olmadıkların belirtmişlerdi. Bunun üzerine Abdullah b. Sehl'in diyeti beytülmâlden ödenmişti ${ }^{35}$. Belâzurî Hayber Yahudilerinin sonıaki dönemlerde de Müslümanlara kötü davranmaya devam ettiklerini belirtir ${ }^{36}$. Meselâ, Hayber'e gelen Abdullah b. Ömer geceleyin uyurken damdan aşağı atılmış ve iki kolu da kurılmışt ${ }^{37}$. Benzer şekilde Muzahhir b. Râfi' isimli bir başka sahabî de Hayber Yahudilerinin tahrikiyle Şam'dan getirilen Hıristiyan işçiler tarafından öldürülmüştü ${ }^{38}$.

Yukarıda bahsi geçen sebeplerden dolayı Hz. Ömer Hayber Yahudilerini sürmeye karar vermişti ${ }^{39}$.

Sürgün kararının Yahudiler üzerinde bir şok etkisi yaratığını tahmin etmek zor değildir. Hatta Hayberlilerden birinin $\mathrm{Hz}$. Ömer'e “Ey müminlerin emiri! Sen bizi topraklarımızdan çıaryorsun; halbuki Hayber'de kalmamızı (Hz.) Muhammed istemişti" şeklindeki serzenişi karşısında Hz. Ömer: "Vaktiyle Resulullah'ın sana 'ilerde Hayber'den çıkarldığında güclü deven seni sürükleyecek', sözünü ne çabuk da unuttun" diye çıkışışt ${ }^{40}$.

${ }^{34}$ Abdürrezzak, el-Musannef, VI, 66 (I Ladis mo. J0019); a.g.e., XI, 28 (Hadis no: 19814); Mes'ûdî, et-Tenbîh ve'l-İşâf, s. 257-258; Ya'kûbî, Târîh, Revrut 1960, II, 56-57; Makdisî, el-Bed ve't-Târîh, Kahire [t.y.], IV, 227. Hz. Peygamber'in bu chlirin etkisini uzun süre hissetioği belirtilir. Bkz. İbn Sa'd, I, 445; Mes'ûdî, a.g.e., s. 258.

${ }^{35}$ Abdürrezzak, el-Musannef, X, 30-31 (Hadis no: 18260); Vâkıdî, 713-715; İ̉n Hişâm, esSîretü'n-Nebeviyye, nşr. Mustafa Sakkâ ve dğr., Beyıut [t.y.], II, 354; Hamidullah, el-Vesâiku'sSiyâsiyje, Kahire 1958, s. 39 (16. Vesîka).

${ }^{36}$ Belazurî, Fütâh, s. 34

${ }^{37}$ Ebû Yûsuf, el-Harâc, s. 51; Belâzurî, Fütûh, s. 36.

${ }^{38}$ Ebû Yûsuf, el-Harâc, s. 51; Vâkıdî, 1I, 716-717.

${ }^{39}$ Hayber Yahudilerinin sürülmesi, Arap yarımadasından gayr-1 Müslimlerin çıkarılmasını beyan eden bazı hadislerle de irtibatlandırılmaktadır. Mesclà bkz. Abdürrczzak, el-Musannef. VI, 56 (Hadis no: 9990); Bclazurî, Fütûh, s. 39-40. Ancak konuyla ilgili araşurmalarıyla tanınan Musıafa Fayda, Hayber Yahudilerinin çıarılmasının hadislerle bir ilgisinin bulunmadığını çcşitli tarihî delillerden hareketle ortaya koymakıadır. Detaylar için bkz. Faycla, Hz. Ömer Zamantnda Gayr-ı Müslimler, İstanbul 1989, s. 191-194.

${ }^{40}$ Buna karşılık Yahudi "O söz bana Ebu'l-Kâsım tarafindan yapulmus bir nükte idi", diye cevap verince, IIz. Ömer "Yalan söylüyorsun!" diyerek Yahudiyi azarlamışı. Bkz. İlın Şcblse, I, I76; Abclürrezrak, el-Musannef, VI, 56 (Hadis no: 9991). 
Hz. Ömer Yahudileri İslâm devleti hududu dışına atmamış, yalnız bir bölgeden başka bir bölgeye yerleştirmiş; topraklarının ve hurmalıklarının kıymetini de tastamam ödemişti ${ }^{41}$.

Ancak sürgünde Yahudilerin tamamının sürülmediği anlaşılmaktadır. Kanaatimize göre sürgünden nasibini alanlar daha çok, yukanda bahsedildiği üzere, Müslümanlar için tehlike teşkil eden Yahudiler olmalıdır. Çünkü Hz. Ömer'in Teymâ ve Yemen'deki Yahudilere dokunmaması, onların iyi hal ve hareket sahibi olmalarından kaynaklanıyordu ${ }^{42}$. Hayber'de Hz. Peygamber'le özel anlaşmaları olan Yahudi aileler de yerlerinde bırakılmış$\mathrm{t}^{43}$. Abdürrezzak'in el-Musannef inde yer alan bilgiye göre $\mathrm{Hz}$. Ömer Yahudileri Hayber'den sürmeye karar verince şöyle bir ilânda bulunmuştur: "Kimin yanında Resûlullah'tan aldı̆̆ bir ahit varsa getirsin! Ben, Hz. Peygamber'le anlaşmast olmayanlan (Hayber'den) süreceğim!"44 İslam kaynaklarından fetih sırasında $\mathrm{Hz}$. Peygamber tarafindan bazı Yahudilere ahit/eman verildiğini biliyoruz. Meselâ, savaşın sürdüğü bir sırada Simâk isimli bir Yahudi gelerek Hayberlilerin askerî sırları hakkında bilgi vermiş ve buna karşllık kendisi, hanımı ve çocukları için Peygamberimiz'den eman almışt ${ }^{45}$. Benzer şekilde Netât'ın stratejik kalelerinden olan Kule kalesi de Ğazzâl isimli bir Yahudinin kale ile ilgili verdiği istihbaratla fethedilebilmiş; bu Yahudi ve ailesine de eman verilmişti ${ }^{45}$. Yine Hayber'in en önemli kalelerinden olan es-Sa'b kalesi de bir Yahudinin yardımıyla ele geçirilmişti. Bölge ile irtibatı gizli bir yeraltu geçidi ile sağlanan bu kalenin fethine yardım ettiği için o Yahudiye de eman verilmişti ${ }^{47}$. İbn Kesîr, Hz. Peygamber'le anlaşması olan Yahudilerin Hayber'den sürülmediklerini belirtir ${ }^{48}$.

Hz. Ömer'in bütün Hayberlileri sürmediğinin bir delili de Peygamberimiz'in hanımların Hayber'deki hisseleri konusunda muhayyer bırakmasıdır. Halife müminlerin annelerinden isteyenin Hayber'deki arazisini alabi-

${ }^{41}$ Fayda, Hz. Ömer Zamanında Gayr-ı Müslimler, s. 184-187. Geç dönemlere ait bir kaynakta Hayber'den eli silah tutan kırk bin erkeğin sürüldüğü belirtilmekıedir. Bk\%. Fyüp Sabri Paşa, Mir'âtü'l-Haremeyn, II, 1225.

42 Bkz. Hamidullah, Islam Peygamberi, I, 601.

${ }^{43}$ Velfenson, s. 186.

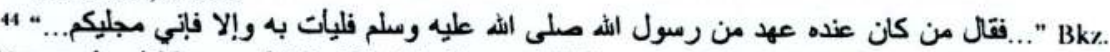
Abdürrezzak, el-Musannef, IV, 125 (I ladis no: 7208); a.g.e., VI, 56 (Hadis no: 9990). Ayrnca bkz. İbn Şclbbc, I, 184; Ilon Kesîr, IV, 219.

${ }^{45}$ Vakıdî, II, 646.

${ }^{46}$ Yahudi kalenin can damanı olan ve kaleyi besleyen su kanalının yerini göstermiş; kale bu kanalın kesilmesiyle fethedilmişti. Bkz. Vâkıdî, II, 666.

${ }^{47}$ Hamidullah, Hz. Peygamberin Savaşlar, s. 189.

${ }^{48}$ İlon Kesîr, IV, 219. 
leceğini, isteyenin de eskiden olduğu gibi gelirini almaya devam edebileceğini söylemiştir $\mathrm{ki}^{49}$, gelirini almaya devam edenlerin toprakları, eski sahipleri olan Yahudiler tarafından işletilmeye devam edilmiş olmalıdır.

Sürgünden sonra Hayber'de Yahudi varlığının bir başka delili de, Peygamberimiz'in Yahudi kökenli eşi $\mathrm{Hz}$. Safiye'nin evliliğine ve ihtidasına rağmen ${ }^{50}$, sonraki dönemlerde de Hayber'deki ailesi ve akrabalarıla irtibatın devam ettirmesidir. Hz. Ömer'in hilafeti sırasında Safiye'nin bir cariyesi halifeye gelerek onun Sebt (Cumartesi/Şabat) gününü hâlâ sevdiğini ve Yahudi akrabalarına da maddi yardımda bulunduğunu söylemişti ${ }^{51}$. $\mathrm{Hz}$. Safiye ayrıca daha hayatta iken mallarının bir kısmını Yahudi akrabalarına vasiyet etmişti ${ }^{52}$. Onun yüz bin dirhem kıymetindeki bir arazisinin üçte birini Yahudi olan bir erkek yeğenine (kız kardeşinin oğlu) vasiyet ettiği, $50 / 670$ veya $52 / 672$ yılında Muaviye zamanında vefâtından sonra ${ }^{53}$ bu vasiyetinin yerine getirildiği rivayet edilmektedir ${ }^{54}$. Bu rivayetten Hayber'de Emevîler döneminde Muaviye zamanında hâlâ Yahudilerin var olduğu anlaşılmaktadır.

Belâzurî'de geçen bir rivayette de ravi Eflah b. Humeyd, Ömer b. Abdülaziz'in, babasını Hayber'deki el-Ketîbe'ye gönderdiğini ve yiyecek alanların varislerine hisselerini tespit edip dağıttığını nakleder. Rivayette Hayber'den yiyecek alanların bir de listesinin olduğu kaydedilmiştii ${ }^{55}$. Emevîler döneminde dağıtumı yapılan bu hisseler, yine Yahudiler tarafından işletilmiş olmalıdır.

49 İbn Şebbc, I, 184, 186; Belâzurî, Fütûh, s. 40.

50 H\%. Saliye Nadiroğulları Yahudilcrinin reislerinden Iluycy b. Shtab'ın kıza idi. Önce Scllâm b. Mişkem'le cvlenmiş, ancak bir süre sonra ondan boşanmışı. Daha sonra Kinâne b. Relổ b. Ebü'l-I lukayk'la evlenen Safiye, Hayber kuşatması sırasıncla kocasını kaybèmişti. Ganimet paylaşımında Dıhye b. Halife'nin sehmine düşen Safiyc, Yahudi ileri gelenlerinden önemli birinin kızı olduğunun söylenmesi üzcre IIz. Peygamlser'in bizzat kendisi tarafindan alınmıştır. Bkı. Vâkıdî, II, 673-674; İbn Sa'd, VIII, 120, 123; Serahsî, el-Mebsût, X, 9; 7clîdî, Sahîh-i Buhân̂ Muhtasan ve Tecrîd-i Sarîh Tercemesi, trc. Ahmed Naim- Kâmil Miras, Ankara 1987, II, 307.

51 Zcbîclî, Tecrîd, II, 306-307, 3. dipnot. Hz. Ömer durumu Safiyc'ye sormuş o da şu cevabı vermişti: "...Sebti, Allah onun yerine Cuma'yı verdiğinden beri sermuiyorum. Yahudilere yardıma gelince; onlar arasinda akrabalarm var. Akrabalık görevimi yerine getiriyorum." Bkz. a.g.e, II, 307.

${ }^{52}$ İbn Sa'd, VIII, 128.

${ }^{53}$ Ilz. Saliye Medine'de Bakî mezarlığına defnedilmiştir. Bkz. İbn Sa'd, VIII, 129.

5H Ibn Sa'd, VIII, 128.

${ }^{55}$ Belâzurî, Fütûh, s. 40. 


\section{Sürgün Sonrası Hayber'de Kalan Yahudiler}

Yahudilerin Hayber'den sürülmesinden sonra şehir ve şehir sakinleri hakkında çok fazla bilgi yoktur. Girişte Yahudi seyyah Benjamin'den naklen Hayber Yahudilerinin kökeninin Ruben, Gad ve Manasse kabilelerine dayandığını belirtmiştik. IX. asıın ikinci yarısında yaşamıs Yahudi seyyah Eldad ha-Dani, seyahatnamesinde, Arabistan Yahudilerinden bahsederken Hayber ifadesini kullanmasa da söz konusu kabilelere dair bazı bilgiler vermiştir. Eldad, Ruben kabilesinin Fârân (Paran) ${ }^{56}$ dağının ardında ikâmet ettiğini, aralarında iyi bir cemaat dayanışması olduğunu nakleder. Bunların savaşa birlikte gittiklerini ve ganimetleri paylaştıklarını belirten seyyah, Rubenîlerin Tevrat tomarı (Sefer Tora), Mişna, Talmud ve Agada gibi metinlere sahip olduğunu; her Sebt (Cumartesi) günü Tevrat'ı İbrânîce metninden okuyup, Ârâmîce olarak tercüme (Targum) ettiklerini söyler ${ }^{37}$. Eldad, Manasse kabilesi ile ilgili olarak ise Mekke şehrinin ötesinde dağlık arazide yaşadıklarını belirterek savaş̧̧ılıklarına vurgu yapar: “...Onlar güslü bir fiziğe ve demir bir yüreğe sahiptir. Çok iyi ata binerler. Geşim kaynaklan sapuldur. Düssmanlarna asla merhamet etmezler. Her biri bin kisisye bedel. ${ }^{58}$ Eldad'ın bu ifadeleri, Hayber Yahudilerini tarif etmektedir.

Sürgün sonrası Hayber hakkında en önemli kaynağımız hadîsçi İbrahim el-Harbî (ö. 285/899) ${ }^{59}$ ile coğrafyacı Bekrî'nin (487/1094) anlatımıdır. Ancak Bekrî'nin anlatımı, ifade değişikliği dışında, Harb̂̂'ninki ile neredeyse aynıdır. Kanaatimize göre ondan iktibas etmiştir.

İfadelerinden şchri bizzat dolaştığı anlaşılan Harbî'nin ziyareti sırasında Hayber'in sınırı Dûme olarak isimlendirilmekteydi. Dûme'den sonra Hayber ve kaleleri gelirdi. Harbî'nin anlatımına göre Hz. Osman zamanında şehre bir çarşı yapılmıştı. Ziyareti sırasında bu çarşı el-Meratta (المرطة) [?]

${ }^{56} \Lambda$ hd-i Atîk'te Hz. İsmail'in annesi Hacer'le birlikıc yaşadığı çöl ve dağ olarak verilen Fârân'ın (Paran) (Tekvin, 17/20; 21/21; 'Tesniye, 33/2), Müslüman ınüclliflerce Mekke dağlarını ifadc ettiği kabul cdilmcktedir. Bkz.. Makdisî, el-Bed ve't-Târîh, V, 32; Yakût, Mu'cem, IV. 225. Yahudi kabulünde ise Fârân, $\Lambda$ kabe körfezi ile Ölüdeniz ve Sina yarımadasının arasında kalan bölgedir. Bk\%. Michael-Avi Yonah, "Paran", EJd, XIII, 88-89. Eldad'in bu ifadesi, Fârân'ın Mekke dağlarını ve Arabistan çölünü ifade ettiğini de göstermekıcdir.

${ }^{57}$ Eldad burada Targum dilini Farsça olarak verir; ancak Ahd-i Atîk'in Ârâmîce tercümclerine "Targum" adı verilmektedir.

58 "Eldad the Dani", nşr. ve İngilizceye trc. Elkan Adler, Jewish Travellers, London 1930, s. 8.

59 Ilayatı için bkı. Zchebî, Siyeru A'lâmi'n-Nübelâ, nşr. Şuayb cl-Arnâvûd ve clğr., Bcyruı 1984/1405, XIII, 356 vd.; İ̉n Kesîr, XI, 79 vd.; M. Yaşar Kandemir, "I larb̂̂", DIA, XVI, 114115. 
olarak isimlendiriliyordu. Hayber kalesinde ise, Hz. Ömer'in soyundan gelen kimseler ikâmet etmekteydi. Daha sonra Vecde kalesi (Hısn-1 vecde) gelirdi. Hurma ve diğer ağaçların bulunduğu bu yer tamamıla $\mathrm{Hz}$. Peygamber'in tasarrufunda idi. Sonra çoğunluğu Hz. Peygamber'e ait olan Selâlim (veya Süleylim), daha sonra da üzerinde Yahudi burçlarının bulunduğu Ehyel dağı, ardından da tarla ve bahçeleriyle ünlü Vatîh uzanırdı. Hz. Peygamber'in hanımlarının ve Muttaliboğulları'nın geçimi buradan (Tu'me) sağlanırdı. Vatîh'ten hemen sonra, ona bitişik olan Ketîbe vadisi gelirdi. Burada, ismini bu vadiden alan Ketîbe kalesi vardı ${ }^{600}$. Hz. Peygamber'in Safiye ile gerdeğe girdiği Sebha mevkisi de burada idi. Hayber kalelerinin en büyüğü ise Hz. Ali'nin fethettiği Kamûs'tu ${ }^{61}$. Hz. Peygamber'in eşi Safiye burada iken esir edilmişti. Burası Yahudi Hukaykoğulları'na aitti ${ }^{62}$. Kalenin hemen altunda $\mathrm{Hz}$. Peygamber'in muhasara sırasında namaz kıldığı yere yapılan Mescid-i Nebevî vardı. Kalenin bitişiğinde uzanan iki vadiden biri Netât, diğeri ise Şı $k^{\prime} t^{63}$. Hayber'de fethedilen ilk ev, Netât'ta idi. Bu ev, Merhab'ın kardeşi Yâsir'e aitti ${ }^{\text {Gt }}$.

Netât ve Şık vadilerinin arası ise Sebha ve Mehâda (veya Muhâda) olarak isimlendirilmekteydi. Vadi, Hz. Peygamber'in fethinden sonra Hayber'de kaldığı yerde yapılan büyük Mescid-i Nebevîye kadar uzanırdı. Bu mescid Abbasî hanedanına mensup vali ve veliaht İsa b. Musa (ö. $167 / 783$ ) tarafindan yaptırılmıştı. Pek çok para harcalıarak yaptırılan mescidin önünde geniş bir alan vardı. Bu alanda bulunan bir taşin $\mathrm{H} z$. Peygamber tarafindan sütre olarak kullanldigi kabul edihnektcydi. Bayram namazları Harbî'nin ziyareti sırasında el-Menzile olarak isimlendirilen bu mescitte edâ edilmekteydi ${ }^{i 5}$.

Harbî'den sonra Hayber hakkında bilgi veren ilk müellif, Hemdanî'dir (ö. 334/945). Hemdanî, Hayber'de Yahudiler ve Mevâlî ile Araplardan Benî Harb, Müzeyne ve Belîyy kabilelerinin yaşadığını belirtir ${ }^{665}$.

${ }^{60}$ Ketîbe, Hayber'den 1 berîd uzaklıktaydı. Bkz. Bekrî, Mu'cem me'sta'cem, II, 521. 1 berîd yaklaşık 24 km.dir. Bk\%. Walther Hınz, İslâm'da Ölçü Sistemleri, trc. Acar Scvim, Istanbul 1990, s. 67 .

${ }^{61}$ Harbî, el-Menâsik ve Emâkinü Turukil-Hac ve Meâlimül-Cezîre, nşr. Hamed Câsir, Riyad 1981, s. 539-540. Ayrica bkz. Bckrî, Mu'cem me'sta'cem, II, 522.

${ }^{62}$ Yâkût, Mu'cem, IV, 213. Yâkût burayı Ğamûd olarak isimlendirir.

${ }^{63}$ I larbî, el-Menâsik, s. 540. Ayrnca bkz.. Bekrî, Mu'cem me'sta'cem, II, 522.

"is Harbî, el-Menâsik, s. 540. Ayrica bkz.. Bekrî, Mu'cem me'sta'cem, II, 523.

${ }^{65}$ I larbî, el-Menâsik, s. 540. Ayrica bkz. Bckrî, Mu'cem me'sta'cem, II, 522.

Gí Ilemdanî, Sifatu Cezîreti'l-Arab, nşr. David Heinrich Müler, Leiden 1884 [ed. Fuat Sczgin, Frankfurt: Institut für Geschichte der Arabisch-Islamischen Wissenschaften, 1993 (Islamic Geography 88)], I, 130. 
Sonraki dönemlerde Hayber'le ilgili bilgiler yok denecek kadar azdır. Yâkût el-Hamevî (ö. 626/1229) kendi zamanında Hayber'in bitişiğindeki el'Arad vadisinde Aneze kabilesinin meskun olduğu dışında bir bilgiye değinmez ${ }^{67}$. Kalkaşendî (ö. 821/1418) Hayber'deki bu kabileyi Yahudi olarak verir $^{68}$. Ancak onun bu bilgisini, Anezelerle beraber yaşayan Yahudiler şeklinde anlamak daha uygundur. İdrisî (ö. 560/1165) ve Kazvînî (ö. 682/1283), Hayber'i hurma bahçeleri ve tarlaları olan küçük bir şehir olarak tarif ederler. Her iki Müslüman müellif de Yahudilerle ilgili herhangi bir bilgi vermemektedir ${ }^{69}$. Hayber o dönemde "Bürdî" adı verilen hurmalan ile şöhret bulmuştu ${ }^{70}$.

Sürgün sonrası Hayber'deki Yahudilere doğrudan atıfta bulunan ve ilk detaylı bilgi veren kaynak, Tudelalı Benjamin'in seyahatnamesidir. Haçlılar döneminde 1165-1173 yılları arasında İslam dünyasını gezen Benjamin'in genelde Arabistan özelde ise Hayber Yahudileri ile ilgili bilgileri gezi ve gözleme değil, şifahî bilgiye dayanmaktadır. Benjamin Hayber topraklarını, Kitab-1 Mukaddes'teki adıyla Yemen (Sebe) topraklanı içerisinde verir. Benjamin'in ifadelerinden Haçlılar dönemi ile Eyyûbîler dönemi başında Hayber Yahudilerinin Teymâ'daki cemaat idaresine (Nesiut) bağlı olduğunu öğreniyoruz. Benjamin cemaat liderinin adın Nasi Hanan olarak verir. ${ }^{71}$ Teymâ ve Hayber Yahudilerinin muhkem şehirlerde bağımsız olarak yaşadıklarını, geçimlerini de ziraat ve hayvancılık yanında komşuları bedevî Araplar gibi yağıma ve çapulla sağladıklarını nakleden seyyah, Hayber Yahudilerinin Ruben, Gad ve Manasse kabilelerinin soyundan geldiğini ve buraya Asur Kralı Salmaneser'in sürgünüyle yerleştiklerini belirtir. Bunlar ayrıca çölde yaşamanın ayrıcalığından da faydalanmışlardır. İnşâ ettikleri sağlam kalelerin yanı sıra, kuş konmaz-keıvan geçmez bu çöl kasabasına kolay kolay ulaşılamadığı için de bağımsızlıklarını koruyabilmişlerdir. Benjamin, Hayber Yahudilerini savaş̧̧ı olarak tanımlar ve aralarında büyük alimlerin bulunduğunu belirtir. Benjamin'in bu ifadeleri, Eldad haDani'den iktibas edilmiş gibidir. Yine o, bütün Arabistan'da Yahudi nüfusunun üç yüz bin, Hayber'de ise elli bin olduğu şeklinde oldukça mübalağalı bir rakam telafuz eder ${ }^{72}$. Nüfus konusundaki abartısı bir kenara bırakılır-

${ }^{67}$ Yâkût, Mu'cem, IV, 103.

${ }^{6 i s}$ Kalkaşendî, Subhü'l-A'şâ, IV, 295.

${ }^{69}$ Bkz. İdrisî, Nüzhetül'-Müştâk fi İhtirâkìl-Âfak, Beyrut 1989, I, 352; Kazvînî, Âsâr'ul-Bilâd, II, 60 .

${ }^{70}$ I Iemdânî, Sifatu Cezîretil-Arab, I, 131.

7 Benjamin, s. 71.

${ }^{72}$ Benjamin, s. 72. 
sa, o dönemde Hayber'de hatırı sayılır bir Yahudi cemaatinin yaşadığı söylenebilir.

Benjamin'den sonra ne Yahudi ne de Arapça kaynaklarda Hayber'deki Yahudilerle ilgili herhangi bir bilgiye rastlanmaktadır. Bu bilgi yokluğu hemen hemen Memlûkler döneminin sonuna kadar da devam etmektedir.

Memlûkler döneminde Hayber'deki Yahudiler hakkında detaylı bilgi veren ilk Yahudi kaynak, Bertinorolu Ovadya'dır (1450-1516). Mişna şârihi Kuzey İtalyalı bu Yahudi din adamı, 1485'te Roma'dan hareketle Rodos üzerinden İskenderiye'ye, oradan da Kudüs'e geçmiş; ölünceye kadar da Filistin'de dinî hizmetlerde bulunmuştu ${ }^{73}$. Ovadya, 1488-1490 yılları arasında İtalya'daki dindaşlarını, yazdığı üç ayıı mektupta doğudaki Yahudi cemaatleri hakkında bilgilendirmiştir. Hayber Yahudileri hakkında ise 8 Elül 5248 (1488) tarihinde yazdığı ilk mektubunda bilgi vermiştir. Ancak onun bilgisi de şifahî anlatıma dayanmaktadır. İskenderiye, Kahire, Filistin ve Habeşistan hakkında bilgi verdikten sonra Ovadya Hayber Yahudileri ile ilgili duyduklarını şu sözlerle anlatır:

“...Musır (veya diğer bölgelerden) Mekke'ye hacca gidenler, ussuz bucaksız tehlikelerle dolu çölü geçmek zorundadır. Bu sebeple hac seferleri dört bin develik kafilelerle gerçekleştirilir. Bu kervanlar sık sık saldırıya uğrar. Bazen çapulcular bu kervanlara bin kişiden müteşekkil gruplarla saldırrlar. Müslümanlar (Yişmaelim) bu çapulcu grubu “Şeday Araplan”, yani “Allah'ın oğullar” olarak isimlendirmektedir. Bunun da sebebi, bu Yahudilerin yağmaya çıkarken Tanrinın adını anmalanndandır. Müslümanlar, bu Yahudilerin omuzunda deveyi taşırken diğer elinde kulıcı ile savaşabilecek kadar güçlü olduğunu söylerler. Bunlar Yahudi olup Rehabîlerin soyundan gelmekte imisler."74

İslamî kaynaklarda Hayber Yahudileriyle ilgili olmasa da, Medine Yahudilerinde Ovadya'nın bahsettiği şekilde bir inancın olduğunu biliyoruz. Talmud Yahudiliğine bağlı oldukları için Hayber Yahudilerinin de onlar gibi inandığını söylemek mümkündür. Bir yönüyle Yahudilikteki "seçilmişlik" anlayışı ${ }^{75}$ ile de bağlantılı olan bu kabule göre, Hz. Peygamber'in çağdaşı Yahudiler, kendilerinin çocuk kadar masum olduklarını; gündüz işle-

${ }^{73}$ Abraham David, "Bertinoro Obadiah, Ben Abraham Yare”, EJd, IV, 698-699; Elkan Adler, Jewish Travellers, London 1930, s. 209.

${ }_{74}$ "The letters of Obadiah Jaré da Bertinoro (1487-1490)", nşr. ve Ingilizceyc trc. Elkan Adler, Jewish Travellers, London 1930, s. 239.

${ }^{75}$ Yahudilikıeki seçilmişlik anlayışı için bkz. Salime Leyla Gürkan, "Kur’ân'a Göre Seçilmişlik Kavramı ve İsrailoğulları'nın Seçilmişliği Mesclesi”, İslâm Araştırmalan Dergisi 13 (2005), s. 25-61. 
dikleri günahın gece, gece işledikleri günahın da gündüz silindiğine inanır$\operatorname{lardı}^{76}$. Hatta Kur'ân'da belịrtildiği üzere, Yahudiler kendilerini "Allah'ın oğulları" ve "sevgilileri" olarak tanımlıyorlardı. ${ }^{77}$ Ovadya'nın belirttiği "ŞeDay" (שדי) ismi ise "Kâdir-i Mutlak Tanrı" (Her Şeye Gücü Yeten) anlaminda olup Yahudilikte Tanri'ya verilen isimlerden biridir ${ }^{78}$. Tevrat'ta da daha çok Hz. İbrahim, İshak ve Ya'kub peygamberler bağlamında değini$\operatorname{lir}^{79}$. Bu açıdan düşünüldüğünde Sami olmaları hasebiyle $\mathrm{Hz}$. İbrahim geleneğine aşina olan Arapların Tanrı'nın Yahudiler tarafindan kullanılan bu ismine pek de yabancı olmadıklarını göstermektedir. Bu aşinalığın Arabistan'da Bertinorolu Ovadya'nın yaşadığı XVI. asıa kadar da devam ettiği anlaşılmaktadır.

1503 yılında Memlûkler döneminde Arabistan'a bir yolculuk düzenleyen Bolognalı (İtalya) seyyah Ludovico di Varthema, Arabistan'da yaşayan bir Yahudi cemaati hakkında bilgi vermiştir. Bazı araşturmacılar seyyahın adını vermediği bu cemaatin, Hayber Yahudileri olduğunu kabul etmektedir ${ }^{80}$. Bazı Müslüman müelliflerin Hayber-Medine arasını 3 gün olarak vermesi ${ }^{{ }^{11}}$ göz önünde bulundurulduğunda, bu kasabanın Hayber olması kuvvetle muhtemeldir. 8 Nisan 1503'te Dimaşk'tan ayrilan Di Varthema, yolda bir Memlâk garnizonu ile karşılaşmış; Mekke'ye girebilmek için kendisini muhtedî biri olarak tanıtarak adının Yunus olduğunu söylemiştir. Dahil olduğu askerî birlik Dimaşk'tan sekiz, Medîne'den üç günlük mesafede, 10-

${ }^{76}$ İbnü'l-Cevıî, Zâdü'l-Mesîr, Beyrut 1404/1983, II, 104.

${ }^{77}$ Mâide, 5/18. Bu anlayıştan olsa gerek Yahudiler Yıllbaşından Kefâret gününe kadar sabah ve akşam ibadetlerinde tövbe işerikli yakarışlar olan "Avinu malkenu" duasında Allah'a "Babâmız..." şeklinde seslenmekıedir. Hz. Peygamber zamanında nasıl okunduğu bilinmese de Abbasîler döneminde Amram Gaon (ö. 871) tarafindan kaleme alınan dua kitabında bu yakaryya yer verilmiştir. Bkz. Amram Gaon, סדור ר' עמרם גאון (Seder) [Amram Gaon'un Dua Kitalı], nşr. ve ing. trc. David Hedegard, Motala 1951, I, 41, İng. trc. 104. Duanın günümüzde okunan metni için bkz. Sidur Kol Ya'kov ke-Minhag Aram-Tusova (סדור קול יעקב כמנהג ארם צובה) (Siddur Kol Yaakob according to Minhag of Aleppo), with English Translation, eds. Rabbi Shimon H. Alouf-Sam Catton-David A. Tawil, Scphardic Haritage Foundation, Inc: USA 1996, s. 143 vd.; Duanın Türkçe tercümesi için bkz. Sidur Kol Yaakov, trc. Liliane Zerbib (Kazes), Ístanbul 2005, s. $136 \mathrm{vd}$.

78 "Şe-Day" ismi Ahd-i Atîk'te bizim tespitimize göre kırk sekiz yerde geçmektedir. Bkz. Behnan Kontgan ve dğr., Kutsal Kitap Dizini (Geniş Kapsaml), İstanbul 2004, s. 862-866 ("Güç" başlı̆ğ); http://www.kutsalkitap.com/kkitap/ ("Iler Şeye Gücü Yeten" anahtar kelimesinden) (24 Şubat 2007).

${ }^{79}$ Meselâ bkz. Tekvin, 17/1; 28/3; 35/11; 43/14; 48/3; C.ıkış, 6/3.

${ }^{80}$ Bkz. Yitshak Ben Tsivi, נדחי ישראל Nidhey Yisrael [Sürgün Israiloğullan], Tel Aviv 1963, s. 188; I. Veccia Vaglicri, "Khaybar", $E I^{2}$, Leiden 1978, II, 1142.

${ }^{81}$ Mescla bkz. Harbî, el-Menâsik, s. 541. 
12 mil uzaklıktan görülebilen tepelerin eteklerinde mukim bir Yahudi kasabasına uğramıştı. Develeri sulamak için durulan bu kasabada, seyyahın ifadesine göre, 4-5 bin kadar Yahudi yaşamaktadır. Di Varthema bu Yahudiler hakkında bazı bilgiler de vermiştir. Geçim kaynaklarının ziraat ve hayvancılığa dayandığını ve sünnet olduklarını nakleden seyyah, Yahudilerin dağın eteğinde bir su deposuna da sahip olduklarını belirterek burada yağmur sularını depoladıklarını nakleder ${ }^{\text {k2 }}$.

Bu asın (XVI. asır) başlarında yaşayan Avraham Forrisol isimli bir Yahudi seyyah da Hayber'de kulübe veya ahşap evlerde pek çok Yahudinin yaşadığını haber verir ${ }^{83}$. Aynı asrın ilerleyen yıllarında Osmanlılar'ın Hicaz'a hakimiyetinden sonra kendini doğrudan Hayber Yahudileriyle ilişkilendiren David Rubenî (Rubenli David) (ö. 1538) isimli bir Yahudinin ilginç bir çabası dikkat çekmektedir. Kendinin Hayber (Habor) çölündeki Ruben, Gad ve Menasse kabilesinin yarısını idare eden Kral Şlomo'nun oğlu ve Kral Yosef in kardeşi olduğunu iddia eden David Rubenî, 15221525 yllan arasında Arabistan'in Cidde limanından hareketle Sudan'a ${ }^{8-1}$, oradan Kahire, Filistin ${ }^{85}$, Hevron ve Kudüs'ü dolaştıktan sonra ${ }^{86}$ İskenderiye üzerinden Adriyatik'teki Pesaro limanına, oradan da Roma'ya geçmiş; Lizbon ve İspanya'yı dolaşmışır. Gezdiği yerlerde dindaşlarına kurtuluş gününün yakın olduğunu müjdeleyen Rubenî, bu uzun yolculuğunda kendisini Hayber kralının komutanı ve elçisi olarak tanıtmış; bu sıfatla da Papa VII. Clement'le (1523-1534) ve onun da tavassutuyla Portekiz kralı III. John'la görüşmüştür. Papa'nın onu Portekiz kralına yönlendirmesinin se-

\footnotetext{
82 Ludovico di Varthema, The Travels of Ludorico di Varthema: in Egypt, Syria, Arabia Deserta and Arabia Felix, in Persia, India and Ethiopia A.D. 1502 to 1508, Italyancadan Ingilizceye trc. John Winter Jones, London 1853 [ed. Fuat Sezgin, Frankfurt: Institut für Geschichte der Arabisch-Islamischen Wissenschafien, 1994 (The Islamic World in Foreign Travel Accounts 2)], s. 22-24. Bu su, muhtemelen cemaat mikvesinde kullanılmak üzere toplanmaktaydı. Yahudi cemaatlerinde genelde sinagogun bitişiği ya da yakınında inşa edlilen mikveler, değişik nedenlerle madelî ve manevî temizliğini kaybeden bir Yahudinin içerisine girip yıkandığı bir havuzdur. Mikveye doldurulacak su da yağmur, kar ve buz gibi tabii kaynakıan olmalıdır. Bilgi, Abbâsîler döneminde yaşamış bir Yahudi din adamının (gaon) responsasında (fetva) yer almakıadır. Responsa için bkı. TĽsuvot ha-Geonim mi-Toh ha-Geniza ( תשובות הגאונים מתוך הגניזה), nşr. Simha Assaf, Yeruşalayim 1929, s. 11 (36. responsa).

${ }^{\text {Bs }}$ Benjamin, s. 143, 146. dipnot (Adler' in notu).

${ }^{84}$ "David Reubeni (1522-1525)", nşr. ve Ingilizccye trc. Elkan Adler, Jewish Travellers, London 1930, s. 251-258.

${ }^{85} \mathrm{Bkz}$. "David Reubeni (1522-1525)", s. 258-260.

${ }^{86} \mathrm{Bkz}$ " "David Reubeni (1522-1525)", s. 261-268.
} 
bebi, Portekizlilerin o dönemde Hind Okyanusu'ndaki faaliyetlerinden dolayıdır ${ }^{87}$.

Hayber komutanı Rubenî'nin tek gayesi vardır: Temsil ettiği güçlü Yahudi cemaatleriyle Osmanlılara ve Hind Müslümanlarına karşı Hıristiyanlara (Portekizlilere), özellikle de Hind Okyanusu'nda destek vermek; buna karşılık Hıristiyanların da Yahudilere Filistin'i vermeleri ${ }^{88}$. Bu sebeple Rubenî, Portekiz kralı ile görüşmesi sırasında Müslümanların boyunduruğundan kurtulmaları ve onlara yardım edebilmeleri için kendisine ateşli silahlar ve bu silahları yapmayı bilen ustalar istemiştir. Rubenî Portekiz kralından ayrıca Yahudileri eğitmesi için talim subayları da talep etmiştir ${ }^{89}$. Kraldan isteklerini koparabilmek için sırf Hayber ve çevresinde üç yüz bin kadar dindaşının bulunduğunu, ayrıca Habeşistan ve Hindistan'da da kalabalık Yahudi cemaatlerinin yaşadığını belirtmiştiı ${ }^{90}$.

Kralın başlangıçta Rubenî'nin teklifine sıcak baktığı anlaşılmaktadır. Hatta kral, Hind bölgesini tanıyan yardımcılarından, o bölgede Rubenî'nin bahsettiği şekilde kalabalık Yahudi cemaatlerinin yaşayıp yaşamadığını sormuş; yardımcıları da başta Singoli (Cranganore) olmak üzere Hindistan'ın değişik yerlerinde pek çok Yahudinin yaşadığını söylemişlerdi ${ }^{91}$. Hakikaten de o dönemde Hindistan'ın en önemli ticaret limanı olan Cranganore'de yarı bağımsız bir Yahudi cemaati yaşamaktaydı. Cranganore Yahudileri Hind racaları tarafından "Mudaliar" adı verilen bir cemaat başkanının idaresi altında idiler. Sayıları o kadar çok idi ki, Yahudiler bağımsız bir krallık statüsü dahi kazanmışlardı ${ }^{92}$.

Kral, Rubenî'ye 1524 yılının Nisan ayında dört bin ateşli silah ve sekiz gemi vereceğini vaat etmiştir ${ }^{93}$. Kralın bu vaadinin Hindistan'daki zengin Yahudilerin desteğini almaya matuf olduğu söylenebilir. Ancak bir süre sonra Rubenî̀yi yanına çağıran kral, sebep zikretmeksizin ne Nisan ayında ne de başka bir zaman kendisine yardım etmeyeceğini; ancak memleketine geri dönmesi için gerekli imkânı sağlayacağını belirtmiştir ${ }^{94}$. Kralın sözünden dönmesinin sebebi seyahatnamede açıklanmamaktadır. Ancak kralın,

\footnotetext{
${ }^{87}$ Bkz. "David Reubeni (1522-1525)", s. 272.

${ }^{88}$ Bkz. "David Reubeni (1522-1525)", s 292.

${ }^{89}$ Bkz. "David Reubeni (1522-1525)", s. 291.

${ }^{90}$ Bkz. "David Reubeni (1522-1525)", s. 292-295.

${ }^{91}$ Bkz. "David Reubeni (1522-1525)", s. 299.

${ }^{92}$ Fischel, "Cranganore", EJd, V, 1059.

${ }^{93}$ Bkz. "David Reulseni (1522-1525)", s. 303.

${ }^{94}$ Bkz. "David Reubeni (1522-1525)", s. 304.
} 
Rubenî'nin bahsettiği Hayber ve çevresindeki Yahudileri soruşturduğu ve o kadar güçlü olmadıklarını anladığı tahmin edilebilir. Hatta, bizzat Rubenî'nin ifadesinden Kudüs, Mısır, Irak ve diğer bölgelerdeki Yahudilerin Osmanlı hakimiyetinden memnun olması dolayısıyla Rubenî'ye destek vermedikleri de anlaşılmaktadır. Zira, cesaret açısından İtalyan Yahudilerini aslana benzeten Rubenî, Osmanlı hakimiyetindeki dindaşlarını korkaklıkla itham eder ${ }^{95}$. Bir diğer gelişme de Rubenî'nin Portekiz'de bulunduğu sırada Huristiyan engizisyonu dolayısıyla zorla Hıristiyanlaştırılan Yahudilerle (Marranos) çok fazla ilgilenmesi, onun bunlara Yahudiliklerini tekrar haturlatıp eski dinlerine olan rağbeti arturma ve hatta döndüreceği endişesidir ki, bu konuda Rubenî, kralın adamları tarafından birkaç kere de uyarilmışur ${ }^{96}$. Rubenî'nin Portekiz'de bulunduğu sırada Cranganore, Portekizliler tarafından işgal edilmişti. Bu işgalde pek çok Yahudi ya öldürülmüş ya da başta Cochin olmak üzere Malabar'daki diğer şehirlere sığınmak zorunda kalmışlardı ${ }^{97}$.

Rubenî'nin Yahudilere Kudüs'te bir yurt verme karşılığında Türkler'e karşı Papalık ve Portekiz krallığı gibi Avrupa devletlerine yardım edeceği bilgisi, Venedik Devlet Arşivleri'nde de dile getirilmiştir. 14 Mart 1524 tarihli bir belgede "Hindistan'dan" ${ }^{(*)}$ Papa'ya bir elçi geldiği, Türklere karşı yapacaklan bir savaşta üs yüz bin Yahudi ile yardim edebileceklerini söylediği ve Papa'dan silah ve mühimmat talebinde bulunduğu" kaydedilmiştir ${ }^{98}$. Bu belge Rubenî'nin Hayberli bir komutan ve elçi sıfatyla İtalya ve Portekiz'i dolaştı̆̆ını teyit etmektedir. Şüphesiz o dönemde Hayber ve çevresinde Rubenî'nin bahsettiği kadar Yahudi cemaati yoktu. Hatta Rubenînin bölgedeki Yahudi nüfusunu üç yüz bin olarak vermesi, bu bilgiyi Tudelalı

${ }^{95}$ Bkz. "David Reubeni (1522-1525)", s. 278.

${ }^{96}$ Mesclâ bkz. "David Rcubeni (1522-1525)", s. 300, 304

${ }^{97}$ E.O. Hoppe, "In Search of the Lost Tribes". The Jewish Quarterly, vol. 6 (No: 1), 22 (Autumn 1958), s. 10; Fischel, "Cranganore", EJd, V, 1059; a.mlr., "Cochin: The Rajahs of Cochin and the Jewish Mudaliar", EJd, V, 623; Adler, Jewish Travellers, XXII. Portckizlilerin I lindistan'a ilk ulaşmaları ve Hindistan'daki Müslüman emirliklerle ilişkileri için bkz.. Y. Hikmet Bayur. Hindistan Tarihi, Ankara 1946, I, 386 vd.; Muhammed Yakub Mughul, Kanuni Devri Osmanlilarm Hind Okyanusu Politikast ve Osmanl-Hind Mïslïmanlan Münasebetleri (1517. 1538), İstanbul 1974, s. 25 vd. Portckizlilerin I find Okyanusu'nda Osmanlı Devleti ilc giriştiği mücadeleler için bkz. Salih Özbaran, "Osmanh İmparatorluğu ve Hinclistan Yolu", İstanbul Ünizersitesi Edebiyat Fakültesi Tarih Dergisi 31 (1978), s. 66 vd.

(*) Ortaçağlarda Habeşistan ve Arabistan'dan Orta Hinclistan (Middle Inclia) şeklincle bahsedilirdi. Meselâ Tudelalı Benjamin, Aden'i Hindistan sınırlan içerisinde verir. Bkz. s. 83. Ayrnca bkz. s. 144, 148. dipnot (Adler'in notu).

${ }^{91}$ Calendar of State Papers (Venetian), 1520-26, s. 810'dan naklen Adller, Jewish Travellers, s. XXI-XXII. 
Benjamin'den"9 naklettiğini göstermektedir. Ancak Hayber'in bu son komutanı(!) Avrupa'da bulunduğu sırada, Hıristiyan zulmü altında yaşayan sözde Hıristiyan özde Yahudi olan (Marranos) dindaşlarına bir umut kaynağı olmuştur. Başta Portekiz'de olmak üzere, İtalya, Tlemsan ve Fez gibi diğer Yahudi cemaatlerinde Hayber'de müstakil bir Yahudi krallığının olduğu şeklinde bir düşünceye yol açmıştır. Bu seyahatnamede yer alan bilgiler, aynı zamanda Hayber Yahudilerinin Osmanlı döneminde dahi hâlâ güç ve kudret sembolü olarak kabul edildiğini göstermektedir.

Rubenî'den sonra doğrudan Hayber Yahudilerinden bahsetmese de, Mekke güzergâhında bazı Yahudi cemaatlerinin yaşadığı, David de Rossi isimli Safedli bir Yahudinin yazdığı mektupta dile getirilmiştir. 1535 yılında yazdığı mektupta Arabistan'da yaşayan Yahudileri değişik kimselere sorduğunu, Safed ile Arabistan çölü arasında uzun bir mesafe olduğu için doğruluğunu teyit edemese de, çölde birtakım Yahudi cemaatlerinin yaşadığının herkes tarafından anlatıldığını belirtir: “... Çok değişik kaynaklardan ve kimselerden tespitime göre Mekke yolu üzerinde, sölde kurduklan çadırlarda pek çok Yahudi yaşamaktaymış. Bunların yakmlarında da aynı şartlarda bedern̂ Araplar yaşarmıs. Bunlar çölden geşen kervanlara baskın düzenler, yağmaladıklan mallan da aralarında paylaşırlarnış. Eğer bunlar şölde bir Yahudiye rastlarlarsa iyi muamele eder, hediyelere boğar ve gideceği yere kadar da götürürlermiş. Bu konuda pek çok olay anlatzld." 100 De Rossi isim vermese de söz konusu Yahudilerin çapulla geçinmeleri, güçlü ve savaş̧ı şekilde tanımlanmaları, diğer seyyahlarin Hayber Yahudileri ile ilgili verdiği bilgilere benzemektedir ${ }^{101}$.

99 Bkz. Benjamin, s. 72

'Dönüş yolunda Rubenî'nin gemisi batma tehlikesi geçirmiş ve Engizisyon tarąifindan hapse atılmış, ancak İmparator V. Charles tarafindan kurtarılmışı. Fakat Yahudiliğe sonradan giren ıalebesi Şlomo Molho ise Mantua'da yakılmışı (1532). Ancak bir süre sonra Rubenî Ispanya'da tekrar hapse atılmış, 1537 veya 1538 yılında hapisıte (Badajoz'da) ölmüştür. Bkz. Shmucl Eutinger, "Reuveni, David", EJd, XIV, 114-116; Adler, Jewish Travellers, s. XXII.

${ }^{100}$ Ben T'sivi, Nidhey Yisrael, s. 189.

${ }^{101}$ Bir sonraki asrın (XVII. asır) ortalarında Arabistan'ı gezen Fransız scyyah Le Blanc Sina Dağı'ndan Mekke'ye giderken güzergâhında sakinlerinin tamamı Yahudi olan bir köyden bahseder: "...Sina Dağindan aynldiktan hemen sonra bir tepe üzerinde kurulmuş olan Cezura (ג'זורה) köyüne ulaşllrr. Köyün neredeyse tamam Yahudilerle meskundur. Yahudiler yan çıplak dolaşrrlar. Avret mahallerini dı̧̧ı da çok fazla bir yerlerini kapatmazlar. Bunlar yaratılıs itibariyle kötü tabiatlı aynt zamanda çok kaba insanlardır." Bkz. Yosef Braslavski, לקר ארצנו עבר ושרידים Le-Heker Artsenu, Avar uSridim [Filistin Üzcrinc Araştırmalar, Geçmiş ve Bakiyc], Hotsaot ha-Kibusı haMeuhad: 'Tel Aviv 1954, s. 48. Le Blanc'in bahsettiği köyün coğrafî konumunu tespit edemediğini belirıen Ben Tsivi, anlatımın kendi zamanında (1950'lerden önce) Edom vadisinde yaşayan Bedül bedevîlerine çok uycluğunu kaydeder. Bkz. Ben Tisivi, Nidhey Yisrael, s. 189-190. 
Bir sonraki asıın başlarında (1703) Hıristiyan seyyah Bartema, Hayber'de bazı Yahudilerin yaşadığını haber verir ${ }^{102}$. Aynı asırda Hayber Yahudileri ile ilgili Danimarkalı seyyah Carsten Niebuhr'un (1761-1767) da bir anlatımına sahibiz. Arabistan'ı gezisi sırasında Hayber'de Benî Mezîd, Benî Şahan ve Benî Aneze kabilelerinin yaşadığını belirten Niebuhr, şunları kaydeder: “...Arabistan'ın ücra köşelerinde Müslümanlarnn hakimiyetinde sadece diğer coğrafi bölgelerden tecrit edilmis Yahudiler değil, Hayber'e komşu Hicaz tepelerinde her biri kendi reisinin idaresinde olan Arap kabileleri de yasamaktadir... Hayberdekiler hariş, diğerleri hakkında da çok fazla malumatım yoktur...Anlatzldığna göre Hayber'deki Yahudiler de aynen Arap kabileleri gibi kendi idarecilerinin hakimiyetinde varlıklarnı sürdürmektedirler. Bunlarn bir kısmı daha önce Müslümanlar tarafindan sürülmüsler. Arabistan'tn kuzeyindeki bütün bölgelerde "Hayberli" kelimesinden daha ağır bir hakaret ifadesi yoktur. Deve kervancilı̆̆ , Hayberlilerin elindedir...Hayber Yahudileri, Arap askerî güçlerine de çok az destek vermektedirler. Hayber Yahudilerinin Arap yarnmadasındaki diğer Yahudi cemaatleriyle de cok fazla irtibatlan yoktur. En azmdan Halep ve Dimaşk Yahudilerinin Hayber'deki dindaşlarıyla irtibatlarının olmadiğın biliyorum. Dimaşk ve Halep Yahudileri onlarn kanun-kural tanımayan Yahudiler veya Karaîler olduğunu düsündükleri için onlardan uzak durmayı yeğledikleri belirtilir." 103

1822 yilında Misyoner Joseph Wolf, Kudüs'te R. Moşe Sakut ve bazı Karaîlerle yaptı̆̆ı görüşmede Hayber Yahudileri ve Yahudilikleri hakkında sormuştur. Sakut, Hayberliler hakkında şunları söylemiştir: “...Allah korusun! Onlar Kudüs'e hiç gelmemişlerdir, inşallah da gelmezler. Yeşu, Israiloğullar'n Filistin'e (Erets Yisrael) getirdiğinde onlar çölde kalmayı tercih etmişlerdir. $O$ zamandan beri de orada, Tevrat bilgisinden mahrun bir biçimde yaşamaktadırlar. Insanlık düsmanı olan Hayber Yahudileri, haydut misali çölde yaşamaktadırlar ve kendilerini Musaoğullan (Bene Moşe) olarak isimlendirmektedirler." 104 Adler bu anlatımı gerçek dışı bulur ${ }^{105}$; ancak anlatımda dikkate alınması gereken bir nokta vardır. $O$ da, Braslavski'nin Wolf tan naklettiği bölümde yer alan bir bilgidir ki, bu nakilde, orada (Hayber'de) yaşayan Yahudilerin (Hz.) Muhammed'i zehirleyen kadının ${ }^{106}$ o bölgede yattığı

${ }^{102}$ Richard F. Burton, Personel Narrative of a Pilgrimage to el-Medinah and Meccah, London 1855 [ed. Fuat Sczgin, Frankfurt: Institut für Geschichte der Arabisch-Islamischen Wissenschaften, 1995 (The Islamic World in Foreign Travel Accounts: 62)], 11, 118, dipnot.

${ }^{103}$ Carsten Nicbuhr, Beschreibung von Arabien, Cophenagen 1772, s. 25'ten naklen Braslavski, Le-Heker Artsenu, s. 49; Ben Tsivi, Nidhey Yisrael, s. 190.

${ }^{104}$ Ben Tsivi, Nidhey Yisrael, s. 190.

${ }^{105}$ Benjamin, s. 142, 145. dipnot (Adler'in notu).

${ }^{106}$ Hz. Peygamber Sellâm b. Mişkem'in hanımı Zeyneb bint-i Hâris tarafindan zchirlenmek istenmiş, ancak Peygamberimiz'in durumu crken fark etmesi üzerine başarılı olamamışt. 
şeklinde bir geleneğe sahip oldukları belirtilmiştir. Aynı nakilde bunların nüfusunun altmış bin civarında olduğu; Arapça ve İbrânîce konuştukları ve bunların Rehabîlerden oldukları da zikredilmiştir ${ }^{107}$.

Tudelalı Benjamin'den sonra İslam dünyası Yahudileri hakkında en detaylı bilgi veren seyyahlardan olan Vilnalı (Litvanya) din adamı David D'Bet Hilel (ö. 1846), seyahatının Dimaşk'la ilgili bölümünde Hayber Yahudilerinden de bahsetmiştir. 1815 yılında Litvanya'dan Safed'e (Filistin) gelen D'Bet Hilel, 1824 yılında çıktığı seyahatinde Filistin, Suriye, Kuzey Irak ve İran içlerine kadar gitmiş; dönüşünde bir yıl Bağdat'ta ikâmet ettikten sonra Hindistan'a geçmişti ${ }^{10}$. Yahudi seyyah Dimaşk'tan kalkan kervanların Medine, Mekke ve Yemen'e gitmek için çölü geçmek zoıunda olduklarını; çölde ise İsrail soyundan Dan kabilesinin yaşadığını belirtir. Reislerinin Derâ'a (?) adlı kasabada oturduğunu haber verir. Dan kabilesinin çölden hac ya da ticarî maksatla geçen Araplardan belli bir vergi de aldıklarımı kaydeden seyyahın ifadesine göre Araplar, bu İsrail kabilesini "Hayber Yahudileri" olarak isimlendirmektedir. Bu Yahudiler zaman zaman Kahire ve İskenderiye'ye giderek oradaki dindaşlarının örf-adet ve yaşantularını gözlemlemektedirler ${ }^{109}$. D'Bet Hilel, Hayber Yahudilerinin Dan kabilesinin soyundan geldiklerini ve Hayber'e de Buhtunnasr'ın Mabed'i yıkmasından yüz elli yll önce yerleştiklerini kaydeder. D'Bet Hilel burada Dan kabilesine mensup Eldad'in rivayetine atffa bulunur ${ }^{110}$. Yine o, seyahatnamesinde 1830 yılında Bombay'da Ya'kov Taylor isimli bir Yahudi tüccarla arasında geçen konuşmadan bahseder. O konuşmada Ya'kov Taylor, D'Bet Hilel'e 1828 yılında Havran'daki ticaret fuarına giden Afrikalı bir dindaşının, Dan kabilesinden (muhtemelen tüccar) bir Yahudi ile karşılaşmasından bahsetmiştir. İfadesine göre arkadaşı sabah (sahrit) ibadetini yaptı̆̆ı sırada bir bedevî yaklaşmı̧ ve tefilinini" ${ }^{\prime \prime \prime}$ öpmüş; ona kendisinin Dan kabilesinden

Ancak aynı zchirclen dolayı sahabeden Bişr b. Berâ vefầ cımişti. Bkz. Abclürrerzak, elMusannef, VI, 66 (Hadis no: 10019); a.g.e., XI, 28 (Iladis no: 19814); Ibn Sa'd, I, 445; Mcs'ûtî, et-Tenbîh ve'l-İşrâf, 256-257; Zchebî, Sijeru A'lâmi'n-Nübelâ, I, 268.

${ }^{107}$ Braslavski, Le-Heker Artsenu, s. 49.

${ }^{108}$ Bkz. David D'Beth Hillel, Unknown Jews in Unknown Lands, edited with an Introduction and Notes by Walter J. Fischel, New York 1973, Neşredenin girişi, s. 12-13.

${ }^{109}$ D'Beth I lillel, Unknown Jews, s. 67.

${ }^{110}$ D'Beth Ilillel, Unknown Jews, s. 67-68. Eldad'ın Dan kabilesi hakkındaki anlatımı için bkz. "Eldad the Dani", s. 9 vd.

III Yahudilerin günlük ibacletlerde takmaları zorunlu olan dua kayışı tefilin, parşömen üzerine 'Tevrat'ıan bölümlerin yazıldığı, şeritlerle birbirine bağh siyah deriden mamul iki küçük kutudan oluşur. Tevrat'taki emre binaen bunlardan biri sol pazuya, diğeri ise başa bağlanır. Tefilin takmak Tevrat'ın bir emridir (Tesniyc, 6/8). Tefilincle Tevrat'tan dörı ayrı 
(Hayberli) bir Yahudi olduğunu söyleyerek kendisiyle kabilesinin yaşadığı yere gelmesini rica etmiş ve kendisini misafir etmekten de çok memnun olacaklarını belirtmiş. Tüccar ona nerede oturduklarını sorunca yürüme yoluyla on, hızlı bir deve ile üç günlük bir mesafede oturduklarını söylemiş...Yahudi tüccar, bu Hayberli Yahudiye kendisiyle Safed'e gelmesini, eşini ve çocuklarını aldıktan sonra beraber dönebileceklerinden bahsetmiş; ancak bedevî Yahudi (Tanrı tarafından) tespit edilen zaman gelinceye kadar Ürdün'ü geçemeyeceklerini söyleyerek reddetmiş ve ayrılmışlar ${ }^{112}$. D'Bet Hilel bütün bu konuşmaların İbrânîce gerçekleştiğini nakleder ${ }^{113}$.

1833'lerde Misır ve civarını gezen Fransız seyyah Baron Bois le Comte, Arabistan hakkında şifahî bilgiye dayanan anlatımında Arabistan halkının Vehhâbî; bazı kabilelerin de Şiî olduğunu belirttikten sonra, Hayber Yahudileri hakkında duydukların da şu sözlerle anlatı:: “...Hayber Yahudileri Rehabîlerdenmiş. Diğer bedevîler gibi, ataerkil ve gösebe bir vaziyette çölde dolaşır; çapul ve yağmactlk yaparlarmıs." 114

1852'lerde Arabistan'ı dolaşan Richard Burton ise, Hz. Peygamber'in çă̆daşı Medine, Hayber, Fedek ve Vâdi'l-kurâ Yahudilerinin kökeni ve bölgeye yerleşmeleri hakkında detaylı bilgi vermekte; ancak kendi zamanında Hayber veya bahsettiği diğer yerlerde Yahudilerin yaşayıp yaşamadığına hiç değinmemektedir ${ }^{115}$.

bölüm (Çıkış, 13/1-10; 13/11-16; Tesniye, 6/4-9; 11/13-21) yazılıdır. Daha fazla bilgi için bk». Abraham Bloch, The Biblical and Historical Background of Jewish Customs and Ceremonies, Ktav Publishing House: New York 1980, s. 78-82.

${ }^{112}$ D'Beth Hillel, Unknown Jews, s. 68.

${ }^{113}$ D'Beth Hillel, Unknown Jews, s. 68.

114 Ben Tsivi, Nidhey Yisrael, s. 191.

115 Verdiği rivayeıtlerden İslam kaynaklarını da okuduğu anlaşılan Burın'un bahsi geçen Yahudilerle ilgili anlatımı için bkz. Burton, Personel Narrative of a Pilgrimage to el-Medinah and Meccah, London 1855 [ed. Fuat Sezgin, Frankfurt: Institut für Geschichte der ArabischIslamischen Wissenschaften, 1995 (The Islamic World in Foreign Travel Accounts 62)], II, 115120. Aynı dönemde (1850'ler) Alman Yahudisi R.Yosef Schwarz. Kızaideniz kenarında, Medinc'ye yakın Yenbû limanında, hayvancalık yanında demir işleri ve ticaret yapan bir Yahudi cemaatinin yaşadığını ve bunların Arap kabileleriyle ticaret dışında irtibat kurmadıklarını yazar. Bu Yahudilerin etrafta "Şabat Arapları" (Aravey Şabat/Sebt gününe riayet eden Araplar) olarak tanındıklarını ve Arapça yanında ibrânîce de konuştuklarını kaydeder. Bkz. Joseph Schwarz, Das Heilige Land, Frankfurt am Main 1852'den naklen Braslavski, Le-Heker Artsenu, s. 49. 
XIX. asrın ikinci yarısında (1862) Arabistan'a yolculuk yapan Yahudi Ya'kov Safir (1822-1885) ${ }^{116}$, Cidde limanında Hayber ve Yahudileri ile ilgili yaptığı araştırmada kendisine anlatılanları Even Safir (אבן ספיר) isimli günlüğüne almıştır. Söz konusu günlükte Hayber ve Yahudileri ile ilgili olarak şunlar kaydedilmiştir: “...Hayber hurma, üzüm ve diğer meyve bahçeleriyle çeurili yessillik bir beldedir. Buradaki bahçelerin bir kısmı (şehre yakın) tepede mukim kimselere diğer yarst ise Firat Nehri kıyısında yaşayan kimselere aittir. Bu bahçelerde Nûbeli siyahî iş̧iler çalı̧̧aktadır. "Hayber Yahudisi" ifadesi buradaki Müslüman Araplar tarafindan biraz aşağılama ve yergi amaçl kullanilmaktader. Onlarn kendi aralarnndaki kavga ya da münakasalannda birbirine hakaret için "Hayber Yahudisi kullklı" (Hayber Yahudisi kadar kötü) ifadesini çok sık kullandığın görürsünüz. Bunun sebebi de, Hayber Yahudilerinin, Peygamberlerine (Hz. Muhammed) düsmanlık beslemelerindendir. Hayber Yahudileri oldukşa kahraman, savaş̧ı ve güçlü insanlardı. (Hz.) Muhammed'in müslüman olun çağrnsın reddetmişler; o da onlarn kökünü kazımıs...Hayber simdilerde tenha bir yer." ${ }^{117}$ Ya'kov Safir, kitabının bir başka yerinde de Hîtli bir Karaî'nin kendisine Hayber Yahudisi (olduğunu söyleyen) yetmiş kadar ailenin Aneze Arapları olarak bilinen bir kabile ile yaşadığını, bunların Rabbanî geleneğe bağlı olduklarını ve Fırat kenarındaki yaşayan Hîtli Yahudi kabilelerini sık sık ziyaret ettiklerini haber verdiğini nakleder. ${ }^{118}$ Hayber'de Aneze varlığından İslam kaynakları da bahsetmektedir. İslam kaynaklarında yer alan bilgiye göre anayurdu Yemâme olan ve câhiliye devrinde Süayr (veya Saîr) ${ }^{119}$ putuna tapan Aneze kabilesi, İslâmiyet'ten sonıa (bir rivayete göre de önce) otlak bulmak için Fırat kıyılarına gö etmişlerdi. Bazıları Kûfe çevresinde yerleşirken bir kısmı da IX. asırda Musul tarafina gitmişti. XII. asırda Aynü't-Temr veya Tüveyk'ten ayrılan Aneze kabilesi mensubu bir grup da Hayber'e yerleşmişti ${ }^{120}$. Aneze kabilesi Hayber'deki varlığını günümüzde de devam ettirmektedir ${ }^{121}$.

${ }^{116}$ Vilnalı (I.itvanya) bir Yahudi olan Ya'kov Safir, 1836'da Kudüs'c yerleşmiştir. 1857 yılında çıkı̆̆ı yolculuğunda Yemen, Scylan, Lindistan, Java, Avustralya ve Yeni Zelanda'yı gezmiş; 1863 yılında Kudüs'c dönmüş ve Even Safir adı verilen scyahatnamesini kaleme almıştır. Seyahatname, XIX. asırda bahsi geçen yerlerdeki Yahudi cemaatleri, özellikle de Yemen Yahudilerinin dinî ve sosyo-kültürel tarihleri açısından çok önemli kabul cdilmekıedir. Bkz. Jehicl Nahshon, "Saphir, Jacol”, EJd, XIV, 852-854.

${ }^{117}$ Ben Tsivi, Nidhey Yisrael, s. 192.

${ }^{118}$ Ben Tsivi, Nidhey Yisrael, s. 192.

119 İbnü'l-Kelbî, Kitâbül'-Esnâm: Putlar Kitabı, trc. ve nşr. Bcyza Düşüngen, Ankara 1969 , 43. Saîr'le ilgili not için bkz. a.g.e., s. 82, 301. dipnot.

120 Firoz Ahmad, "Anaza”, Encyclopedia of the World Muslims, cds. N.K. Singh-A.M. Khan, Delhi 2002, I, 51 : Abdülkerim Özaydın, "Aneze", DIA, III, 196.

${ }^{121}$ Bkz. Ilammûd b. Dâvî cl-Kcsâmî, Şimâlü'l-Hicâz, s. 201. 
Ya'kov Safir, San'a'da bulunduğu surada da Dan kabilesine mensup olduğunu söyleyen bir Yahudi aile ile tanışmıs, aile ona aslen Hayberli olduklarını, kabile üyelerinin hâlâ Arap çölünün içlerinde yaşadığını haber vermiştir ${ }^{122}$. Yine Safir Yemen'de İsmailî Arap ve bedevîlerle barış içerisinde yaşayan Yahudilerin bulunduğunu; bunların dinleri hariç, her şeyleriyle bir Arap gibi olduğunu ve dinî gereklere de dikkat ettiklerini haber verir. Haklarında hiçbir araştırmanın yapılmadığı bu Yahudilere "Hayberliler" dendiğini ve bu ifadenin biraz da aşağılayıcı bir mahiyette kullanıldığını söyler ${ }^{123}$. Safir'in ifadelerinden Hayber Yahudilerinden bazılarının, sonraki dönemlerde Yemen'e de gittikleri anlaşılmaktadır.

XIX. asırda Arabistan'ı gezen Huristiyan seyyahlar Hayber'de Yahudi varlığına işaret etmemektedirler. Ya'kov Safir'den beş yıl sonra Şubat 1864'te Hayber'i ziyaret eden İtalyan seyyah Carlo Guermani, Hayber sakinlerinin Sudanlılar'ı andıran siyahî insanlar olduğunu; nüfûsları yaklaşık 2.500 kişi olan bu insanların yedi ayı mahallede yaşadığını; Hayber'in de Teymâ gibi etrafının hurma ağaçlarıyla çevrili bir mezra olduğunu kaydeder. Guermani'nin ziyareti esnasında vadiye hakim bir tepede bulunan ve ilk fethi sırasında Hz. Peygamber tarafindan alınan Merhab(a) Kasrı, Yahudi Kasıı (Kasru'l-Yahûd) olarak isimlendirilmekteydi ve hâlâ da ayakta idi." Guermani Hayber halkı ile ilgili olarak da şu bilgileri verir: “...Hayber halkı Veled Süleyman'a satzlan Habesistan ve Mûr (Morisko/Moor) ${ }^{124}$ kölelerin neslindendir. Köleler efendileri ile beraber kalmıslar; ancak birkaç asir önce burada bir çiçek (hastalı̆̆ı) salgını yaşanmı̧. Halk bu hastalı̆ın Hayberin suyundan kaynaklandığın belirtir...Veled Süleyman Hayber’i mutat olduğu üzere ziyaret eder; ancak Hayber'in suyunun özellikle beyaz tenli insanlara zararlı olduğu inanctndan dolayı şehre girmez. Beyaz insanlara ait arazilerin ekim-dikim işleriyle bu siyahî iş̧iler uğraşır ve bunlar Tallâl b. Reşid'e 9.320 Frank ya da 2.000 thaler $^{125}$ kira

122 Ben Tsivi, Nidhey Yisrael, s. 192. Yemenli Yahudi tarihçi Ilayyim I labşâş (ö. 1899) Necrân Yahudilerinclen, Yahudi kabilcleri Dan ve Ruben hakkında çok değişik hikaycler dinlediğini ve kendilerinin de o kabilenin torunlarından olduğu iddliasında bulundukların nakleder. Bkz. Ben T'sivi, Nidhey Yisrael, s. 192.

${ }^{123}$ Ben Tsivi, Nidhey Yisrael, s. 193.

- Bu kasır günümüzde de ayaktadır. Bkz. Makalenin sonundaki resimler.

124 İspanya'nın Müslümanlar tarafından fethinden sonra yerli halkıan İslam'a giren kimseler. İspanya'nın Müslümanların elinden çıkmasından sonra (1492) bu kimselerden Müslümanlığa bağlı olanlar "Mudaccenin" (Mudejares); zorla Hıristiyanlaşıırlanlar ise "Morisko" olarak isimlendirilmişlerdi. Bkz. Hitti, Siyasi ve Külttürel İslam Tarihi, trc. Salih Tuğ, İstanbul 1995, III, 862; Muhammed İmamüddin, Endülüs Siyasi Tarihi, trc. Yusuf Yazar, Ankara 1990, s. 349.

${ }^{123}$ XVI. asırda Almanya'nın Joachimsthal kasabasında darbedilen bir para birimidir. 1873 yılında NIman markının kabulüne kadar tedavülde kalmıştır. "Dolar"ın (dollar) bu kelimeden 
öderler. Yükümlü olduklan baska bir vergi de yoktur. Hayber'de yasayan kabilelerin reisi ise Habeş kökenli Hâmid b. Şamamî'dir. Bunlarn hepsi de Müslümandır." ${ }^{126}$ Guermani, Hayber'de herhangi bir Yahudi varlığından bahsetmez; ancak bahsettiği siyahîler Hayber'de varlığını bu gün de devam ettirmektedir ${ }^{127}$.

XIX. asırda Arabistan'ı gezen bir diğer Huristiyan seyyah Charles M. Doughty ise, Hayber Yahudileri ile ilgili o dönemde ağızdan ağıza dolaşan rivayetlere pek değer vermez. Ancak Doughty'nin gözlemleri, o dönem Hayberi ile ilgili en iyi anlatım olması yönüyle kıymet taşımaktadır. İfadesine göre halk, Ma'an halkının Yahudi kökenli olduğunu kabul etmekte$\operatorname{dir}^{128}$. Doughty, Teymâ şeyhi Ali es-Süveysî'nin Yahudi kökenine işaret eden "el-Yahudî" nisbesi ile çağrıldığını belirtir ${ }^{129}$. Hayber'deki kale, onun ziyareti esnasında da "Yahudi Kasrı" (ya da Kalesi) olarak isimlendirilmekteydi $^{130}$. Doughty'nin ziyareti sırasında Hayber'in banliyösünde şenşakraklığı ile tanınan Fehyat ya da Hetîm (veya Hütcym) adlı bedevî Arap kabilesi oturmaktayd. Hetîm kabilesi günümüzde de Hayber'in sakinlerindendir ${ }^{131}$. Doughty bunlan Hayber reisi Merhab'la irtibatlandirır ve bunların Hayber'in en eski sakinleri, atalarının ise Hayber Yahudileri olduğunu nakleder ${ }^{132}$. Doughty, Hayber'de mukim Veled Ali kabilesine mensup bazı ailelerin Hayber Yahudilerinin soyundan geldiklerini söyler ${ }^{133}$.

Doughty, seyahatnamesinin bir başka yerinde de Bağdat'ta asaletiyle ünlü bazı Yahudi aileler ile Hindistan'da ticaret yapan bir tüccarın kendisine, kendilerinin Hayber Yahudilerinden olduklarını söylediğini nakleder ${ }^{134}$. Hristiyan seyyah, o dönemde Yahudilerin, Hayberli dindaşlan ile ilgili efsanevî pek çok bilgiye sahip oldukların belirterek onların, Hayberlileri İsrailoğulları'nın Rehab soyundan geldiklerine inandığını söyler ${ }^{135}$. Doughty Hayber'i de detaylariyla anlatur ${ }^{136}$.

türetildiği kabul edilmektedir. Bkz. http://www.infoplease.com/ce6/world/A0825791.html; http://www.britannica.com/cb/article-9030828/dollar (25.Mart.2007).

${ }^{126}$ Ben Tsivi, Nidhey Yisrael, s. 193.

${ }^{127}$ Bkz. Hammûd b. Dâvî el-Kesâmî, Şimâlü'l-Hicâz, s. 201.

${ }^{128}$ Charles Montagu Doughty, Travels in Arabia Deserta, London 1923, I, 34.

${ }^{129}$ Doughty, Travels in Arabia Deserta, I, 285.

${ }^{130}$ Doughty, Travels in Arabia Deserta, I, 13.

${ }^{131}$ Bkz. Hammûd b. Dâvî el-Kesâmî, Şimâlü'l-Hicâz, s. 201.

${ }^{132}$ Doughty, Travels in Arabia Deserta, I, 318.

13s Doughty, Travels in Arabia Deserta, I, 389-390.

${ }^{134}$ Doughty, Travels in Arabia Deserta, II, 127.

${ }^{135}$ Doughty, Travels in Arabia Deserta, II, 127.

${ }^{136}$ Bkz. Doughty, Travels in Arabia Deserta, II, 77 vd. 
Ben-Tsivi kesin olmasa da genelde Arabistan, özelde ise Hayber'deki Yahudi varlığının XVIII. asıın ikinci yarısından itibaren Vehhâbî hareketi ile beraber yavaş yavaş son bulduğu kanaatindedir ${ }^{137}$.

\section{Sürgün Sonrası İslâm Dünyasının Değişik Yerlerinde Hayber Ya- hudileri}

Hz. Ömer Hayber Yahudilerini Erîha ve Teymâ'ya sürmüştü ${ }^{138}$. Hayberlilerin buraya sürülmelerinin sebebi, eskiden beri bu iki şehirde de Yahudi cemaatlerinin yaşaması olmalıdır. Hayber Yahudilerin Erîha ve Teymâ'ya sürgünlerinden sonraki hayatlarına dair bilgiler yok denccek kadar azdrr.

Yerleşim birimi olarak tarihi çok eski dönemlere dayanan Erîha, Hz. Musa'dan sonra yapılan toprak dağıtımında Bünyamin kabilesine verilmişti $^{139}$. Daha sonraki dönemlerde İlyâs ve Elyesa' (Eliyahu ve Elişa) peygamberlerin burada yaşadığı dışında ${ }^{140}$ Erîha ile ilgili başka bilgi yoktur. Bâbilliler'in Filistin'e saldırısından sonra tahrip olan şehir, sürgün sonrasında tekrar inşâ edilmiş ve 345 Yahudi (aile) iskân edilmişti ${ }^{141}$. Erîha Helen döneminden itibaren yavaş yavaş önemini kaybetmiştir. Roma'ya karşı yapılan birinci Yahudi savaşında (66-70) tahrip edilen şehir, sonraki dönemlerde Roma'nın askerî bir üssü olarak kullanılmıştı ${ }^{142}$.

Yahudi kaynaklarda Hz. Peygamber zamanında Medine'den sürülen Nadîroğulları'nın bir kısmının Erîha'ya yerleştiği şeklinde bir bilgi yer almaktadır ${ }^{143}$. Illk halifeler döneminde burası Filistin ordugâhına (Cündü Filistin) bağlıydı ${ }^{144}$. Emevîler döneminde 724 yılında Halife Hişâm tarafindan bir yazlık yaptırılan Erîha'nın ${ }^{145}$ İslamî dönemdeki en önemli geçim

${ }^{137}$ Bkz. Ben Tsivi, Nidhey Yisrael, s. 196-197. Bunların bir kısmının başka yerlere gö ç ctiği, bir kısmının da Doughty'nin bahsettiği gibi, İslam'a girdiği tahmin edilcbilir. Ben-Tsivi 1929 ve 1930 yıllarında değişik Araplardan H layber ve Hayber Yahudileri ile ilgili sorular sormuş ve anlatılanları da kaydetmiştir. Ben-Tsivi'nin kayıları için bk». a.g.e., s. 197-202.

${ }^{13 *}$ Abdürrezzak, el-Musannef, VI, 55 (Hadis no: 9989).

${ }^{139}$ Yeşu, 18/21.

140 II. Krallar, 2/4, 18.

${ }^{1+1}$ Nehemya, $7 / 36$.

${ }^{142}$ Nachman Avigad, "Jericho", EJd, IX, 1367-1368. Savaşla ilgili olarak bkz. Sharon, İsrail Ulusunun Tarihi, Yeruşalayim 1981, s. 74-75.

143 "Jericho", EJd, IX, 1369.

144 Gil, (634-1099) ארץ-ישראל בתקופת המוסלימית הראשונה - Erets-Yisrael bi'Tkufat haMüslimit ha-Rişona [İslamî Dönemde Filistin], Yeruşalayim 1983, I, 91-92.

${ }^{145}$ Bkz. Gil, Erets Yisrael, I, 88. 
kaynağı, kumaş boyası yapılan çivit ve hurma yetiştiriciliği idi ${ }^{146}$. Şehirde masoretik çalışmaların da yapıldığı anlaşılmaktadır ${ }^{147}$. Gil, burada istinsah edilen "Sefer Yeriho" (ספר יריחו) isimli bir Tevrat nüshasından bahseder ${ }^{148}$. Erîha ile ilgili Geniza dokümanlarına da nerdeyse hiç bilgi yansımamışur. 1042-1043 tarihli bir Geniza dokümanında Fustat'ta Filistinliler cemaatine vakfedilen bir evde Erîhalı bir Yahudinin (אלריחאני/el-Rihanî) ikamet ettiği kaydedilmiştir ${ }^{149}$. Erîha 1099 yılında Haçlılar tarafından işgal edilmiş ve bu işgal Salahaddîn Eyyûbî'nin istirdadına kadar (1187) devam etmiştir ${ }^{150}$.

Hayber Yahudilerinin gittiği bir diğer şehir Teymâ da Yahudilerin Arabistan'da yerleştikleri ilk yerleşim birimlerinden biriydi. Kalkaşendî'de yer alan bir rivayette Yahudilerin, Arabistan'a düzenledikleri ilk seferlerden birisinin Teymâ üzerine olduğu belirtilmektedir. Rivayete göre $\mathrm{Hz}$. Musa Hicaz Bölgesi'nde taşkınlık yapan Âmâlikalılar'a karşı bir ordu gönderir ve askerlerine muzaffer olmaları halinde düşmanın hepsini kılıçtan geçirmelerini emreder. Gönderdiği ordu muzaffer olur; Âmâlika Kralı dahil herkes öldürülür; ancak kralın oğlu çok küçük olduğu için merhamet edilir ve serbest bırakılır. Ordu Şam'a (Filistin) döndüğünde $\mathrm{Hz}$. Musa vefât etmiştir. Savaştan dönenler İsrailoğulları'na durumu anlatırlar. Ancak İsrâiloğulları onları, Âmâlikalılar'ın hepsini öldürmedikleri için emre karşı geldiklerini söyleyerek cemaate kabul etmezler. Bunun üzerine onlar da mağlup ettikleri Âmâlikalılar'ın topraklarına dönerek yaşamaya başlarlar ${ }^{151}$.

146 Bkz. Mukaddesî, Ahsenü't-Tekâsîm fi Ma'rifeti'l-Ekâlîm, nşr. M.J.de Gocjc, E.J.Brill: leiden 1906, s. 175; İbnü'l-Fakîh, Kitâbüll-Büldân, s. 515.

147 Bugün Yahudilerce muteber Ahd-i Atîk metni, "masoretler" (masoretik metin tedvin eden kişiler) tarafindan önceki metinlerden fayclalanılarak İslamî dönemcle X. asra kadar yapılan çalışmalar neticesinde tespit edilmiş ve bu günkü şeklini almıştır. Ahd-i Atîk'le ilgili bu çalışmalar, "Kâtipler" adı verilen "Masoret" (Ba'aley masora) ya da "Soferim" tarafinclan yapılmıştır. Yahudi literatüründe bunların çalı̧̧malarına "gelenck" anlamında "Masora" "ענינים שונים הניגעים לתקופת הגאונים" adı verilmiştir. Bkz. Samuel Poznanski, "'Inyanim Şonim ha-Noga'im li"Tkufat ha-Geonim" [Gaonluk Döncmine Dair Değişik Konular], ha-Kedem no.1-4 (1907), s. 134; Gractz, III, 111-112; Masoretlerin çalışma usulü hakkında bkz. Salo Wittmayer Baron, A Social and Religious History of the Jews, New York 1957, VI, 249 vd. Bugünkü Tevrat'ın tespit süreci için bkz. Baki Adam, Yahudi Kaynaklara Göre Tevrat, Ankara 1997, s. $86 \mathrm{vd}$.

148 Gil, Erets Yisrael, I, 151. 194-195.

${ }^{19} \mathrm{Gil}$, Documents of the Jewish Pious Foundations from the Cairo Geniza, Leiden: Brill 1976, s.

150 "Jericho", EJd, IX, 1369.

${ }^{151}$ Kalkaşendî, Subhü'l-A'şâ, IV, 294. Aynı rivayet, Tcymâ bahsedilmeksizin Ebu'l-Ferec clİsfahânî tarafindan da nakledilmektedir. Bkz. Kìtab'ül-Eğânî, nşr. Scmîr Câbir, Beyrut 1986, III, 110. 
Rivayet doğru kabul edilirse, Yahudilerin Teymâ'daki kökenlerinin $\mathrm{Hz}$. Musa dönemine kadar dayandığı söylenebilir. Müsteşrık A. Müller Kalde Kralı Nabonidus'un (M.Ö. 559-539) Teymâ şehrine düzenlediği bir seferde askerleri arasında Yahudilerin de bulunduğunu ve Teymâ'da kalıp zamanla Teymâ ile Yesrib arasındaki bazı yerleşim birimleri ile Vâdilkurâ gibi yerlere yayıldıklarını belirtir ${ }^{152}$. Müller'in bu izahı makul görünmektedir. Kitab-ı Mukaddes'teki "Tema" şeklindeki atıflar bir yana ${ }^{153}$, Teymâ Yahudilerine Talmud'ta da atıfta bulunulmaktadır. Talmud'ta (Zebahim, 32b) zikı geçen Rabbi Şimon'un Teymâlı olduğu belirtiliı ${ }^{154}$. Teymâ aynı zamanda sadakatiyle meşhur olmuş cahiliye dönemi şairi Samavel b. 'Âdiyâ'nın da memleketi idi ${ }^{155}$. Teymâ Yahudilerinden bir Arap kabilesinin Yahudileşmesi bağlamında da bahsedilir. Bekrî'nin rivayetine göre, Belîy kabilesinin bir kolu olan Benî Hışne, cahiliye döneminde Teymâ'ya sığınmak istemiş, ama buradaki Yahudiler dini farklı olduğu için onları kabul etmek istememişler, bunun üzerine kabilenin tamamı Yahudi dinini benimsemişti ${ }^{156}$.

Hz. Peygamber zamanında Teymâ Yahudileri Hayber Yahudilerinin mağlubiyetinden ve Vâdi'l-kurâ'nın teslimiyetinden sonra Hz. Peygamber'le anlaşmış; cizye ödemeleri şartıyla topraklarında bırakılmışlard ${ }^{157}$.

Teymâ Yahudilerinin sonraki dönemlerdeki durumuyla ilgili İslâm kaynaklarına yansıyan yegâne bilgi, Sümeyr adlı Teymâlı bir Yahudinin Abdülmelik tarafından para basımında görevlendirilmesidir ${ }^{158}$. Gümüşten bastırılan paralara ona nispetle Sümeyriye adı verilmişti ${ }^{159}$. Sonraki dönem-

152 A. Müller, Der Islam, I, 36'dan naklen, Torrcy, s. 17-18; Cevâd Ali, VI, 513, 527. Ayrica lJky. "Tayma", EJd, XV, 874; Hamidullah, "Hayber", DIA, XVII, 20. Teymâ şehrine Asur İmparator'u III. Tiglat-Pilasar (m.ö. 745-727) zamanında da bir sefer düzenlenmişti. Bkz. Hitti, I, 63; Günalıay, Yakm Şark Elâm ve Mezopotamya, Ankara 1987, s. 557.

${ }^{153} \mathrm{Bkz}$. İşaya, 21/14, Yeremya, 25/23.

${ }^{154}$ Joseph Horovitz, "Judaco-Arabic Relations in pre-Islamic Times", Islamic Culture (1929), s. 172.

${ }^{155}$ Hemdânî, Sifatu Cezîreti'l-Arab, I, 131; Mes'ûclî, et-Tenbîh ve'l-Işrâff, s. 258.

${ }^{156}$ I Iorovit\%, s. 177.

${ }^{157}$ Bclâzurî. Fütûh, s. 48.

15k Makrizî, en-Nukûdül-Kadîmetül-İslâmiyye, trc. İbrahim Ilakkı Konyalı, İstanbul 1946, s. 36 .

${ }^{159}$ Belâzurî, Fütûh, s. 656. İbnü'l-Esîr ise, kendisinden laşkasının para bastırmasını yasaklamasına rağmen Yahudi Sümeyr'in idareden habersiz dirhem bastırdığını öğrenen Haccâc'ın onu öldürmek üzere tutukladığını, ancak Sümeyr'in halkın alışverişlerinde birbirini kandırmasını önlemek için bir tcrazi hazırladığını, o zamana kadar terazisi olmayan ve bu scbeple paraları birbiriyle tartan halkın, tcrazinin hazırlanmasından sonra birbirini aldatma ihtimalinin ortadan kalkığını belirtir İbnü'l-Esîr, el-Kâmil fi't-Târîh, nşr. C.J. Tornberg. Beyrut 1965, IV, 417 . 
lerde Teymâ Yahudileri ile alakalı en erken bilgi ise, XII. asır Yahudi seyyahlarından Tudelalı Benjamin tarafından verilmiştir. Benjamin, Teymâ'nın o bölgede yaşayan Yahudilerin idare merkezi olduğunu belirtir. ${ }^{160}$ Hayber Yahudileri de bu sırada muhtemelen buraya bağlı olmalıdırlar. Teymâ'daki Yahudi cemaatinin R. Hanan ha-Nasi tarafından idare edildiğini belirten seyyah şehir hakkında şu bilgileri verir:

“...Burast on altı günlük genişliği olan bir şehirdir. Şehrin kuzey tarafi dağlarla çevrilmiştir. (Bu civarda) Çok sayıda genis ve muhkem şehirlere (yerleşim birimlerine) sahip olan Yahudiler yabancularn (gentiles) boyunduruğu altında değildir. Ganimet elde etmek için komsu ve müttefikleri olan Araplarla birlikte uzak memleketlere yağma seferlerine şıkarlar... Bu amaşla Şinar (Irak) ve Yemen topraklarna sefer düzenlerler. Burada yaşayan Yahudilerden bütün komşulan korkar. Yahudilerden çiftçilik ve hayvancilık yapan kimseler de vardır. Arazileri geniştir. Aralarnda dindar, alim ve akıll kimseler yaşamaktadır. Yahudiler sahip olduklan seylerin onda birini akademide çalı̧̧alar yapan ilim adamlarna, Sion ve Kudüs'ün yaşllarna ve fakirlerine, dünyadan el-etek çekmiş münzevî bir hayat yaşayan zâhidlere verirler." ${ }^{161}$

Sürülen Hayber Yahudilerine sonraki dönemlerde daha çok cizye vergisi ve müslüman idarecilerin gayr-1 Müslimlerle ilgili yaptığı düzenlemeler bağlamında değinilmektedir. Hayberliler veya Hayberli olduğunu iddia eden bazı Yahudiler, Hz. Peygamber döneminde kendilerinden cizye alınmadığını belirterek tarihî belge süsü verdikleri bazı düzmece belgelerle dönemin idarecilerinden kendilerini cizyeden muaf tutma talebinde bulunmuşlardır. Cizyeden muafiyet taleplerinin dile getirildiği rivayetlerden, onların İslam dünyasının değişik şehirlerine dağıldıklarını da anlıyoruz. İslâm hukukuna göre gayr-1 müslimlerin seyahat etme, taşınma ve istedikleri yerde ikâmetleri konusunda herhangi bir engel bulunmadığı için ${ }^{162}$ Hayber Yahudileri sonraki dönemlerde Erîha ve Teymâ'dan ayrularak değişik şehirlere yerleşmişlerdir. Hem Yahudi hem de İslam kaynaklarından Hayber Yahudilerinin yerleştikleri bazı şehirleri tespit etmek mümkündür.

160 Benjamin, s. 71.

161 Benjamin, s. 71. Benjamin'in burada bahsettiği zahitler Siyon Ağıtçularidır (Avele Tsion). Yinc onun anlatımına göre bu kimscler mağaralarda veya yeralındaki cvlerde yaşar, sebt (şabat) ve bayram günleri hariç bütün sencyi oruçla geçirir, kendilerine, Yahudi kardeşlerine, Teymâlılar'a rahmet ve merhamet etmesi için Büyük Bir'e (Rab) dua colcrlerdi. Bkz. a.g.e., s. 71.

162 Bkı. Ehû Yûsuf, s. 127. 
Kaynaklara geçen bilgilerden Hayberlilerden bazılarının Mısır'a yerleştiğini anlıyoruz. XI. asra ait bir Geniza dokümanında [British Museum. Or. 5544, Fol. 9] Mübarek b. Vehb isimli Taberiyeli bir Yahudinin, Fustat'ta mukim akıabası Halfe b. İbrahim'e yazdığı bir mektubunda yer verilmektedir. Dokümanda Halfe b. İbrahim'den, Tabip (ha-Rofe) İbnü'l-Hayberî olarak bahsedilmektedir. Braslavski, söz konusu tabibin Fustat'ta mukim Hayberli bir Yahudi olduğunu belirtir ${ }^{163}$. Dokümanda özetle Mübarek b. Vehb, tabip İbnü'l-Hayberîyi Filistin'de ikamet etmeye davet eder. Eğer Filistin'e gelme niyeti varsa, Remle (ya da Kudüs) gibi yaşam şartlarının zor olduğu şehirlere değil, ekmeğin en ucuz olduğu Taberiye'yi tercih etmesini tavsiye eder ${ }^{114}$.

XII. asra ait bir dokümanda da Yahîn isimli bir Yahudi şairin Mısır'ın el-Mahalle isimli Yahudilerle meskun semtinde otururken, kendisinden cizye ödemesi istendiği; ancak onun Hayber Yahudilerinden olduğunu belirterek bunu reddettiği belirtilmektedir ${ }^{165}$.

Braslavski'nin neşrettiği Cambridge Üniversitesi'nde kayıth [T.S. 18.2, Fol.3] bir başka dokümanda, Askalân'da mukim Avraham bar Halfon ben Nahum tarafindan (Fustat) bet din(in)de parnaslık yapan Eli ha-Kohen'e ait bir mektup yer almaktadır. Söz konusu mektupta Hayber Yahudilerinc tesadüfen bir atıf yapılmaktadır. Braslavski'nin muhteva olarak bahsettiği mektubun sonunda Avraham bar Halfon, Eli'ye, Mervân b. Hasan'a selam söylemesini ve ona arkadaşı Salih b. Müslim'in getirdiği "Hayberlilerin mektubunun (Kitâbül-Hayâbir) henüz ulaştığın”" haber vermesini rica eder $^{166}$.

- Hayberli, Hayberlinin oğlu.

${ }^{163}$ Aynı doküman bazı çalışmalarında kullanan (Gil ve Coitein isc, bu görüşıc değildir. Goitcin, Braslaviski'nin "אלכיבר" (cl-Hayber) şcklinde okuduğu kelimeyi "אלכביר" (cl-Kebîr) şcklinde okumuşıur. Bkz. Goitein, A Mediterranean Society, Berkelcy: University of California 1967-1988, II, 589, 8 dipnot. Yahudice-Arap̧̧a doküman, İbranice tercümesiyle beraber Gil tarafindan da neşredilmiştir. Bkz. Erets Yisrael, II, 450-452.

164 Bkz.. Braslavski, "יהודי כיבר בארץ-ישראל בסוף התקופה הערבית" "Yahudey Ilaylser beErets-Yisrael be-sof ha-Tkula ha-'Aravit" [İslamî Dönemin Sonunda Filistin'de Ilayber Yahudilcri], Yediot ha-Hevra ha-'Ivrit le-Hakirat Erets-Yisrael ve 'Atikoteha (BJPES), 7 (1940), s. 79)-80.

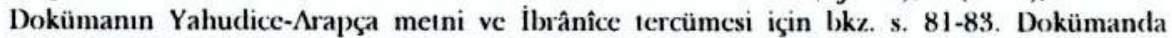
Taberiye'de ekmeğin 1 rutılının 1 dirhem olduğu belirtilir. $O$ dönemde Filistin bölgesinde 1 ntıl 2.5 kg'a denk bir ağırlık birimi iđli. Bkz.. Ilınz, İslâm'da Ölçü Sistamleri, s. 36-37.

165 Goilcin, A Mediterranean Society, II, 386.

${ }^{166}$ Braslavski, "Yahudey Hayler be-Erets-Yisracl be-sof ha-T kufa ha-'Aravit", s. 80-81. 
Geniza dokümanlarında yer alan başka dokümanlardan Hayberlilerden bazısının da Taberiye'ye yerleştiğini öğreniyoruz. Şehirde mukim Hayberlilere 1030 tarihli bir dokümanda atıf yapılmıştır. Dokümanın baş tarafı günümüze ulaşmamıştır. Ancak içeriğinden anlaşıldığı kadarıyla Sibâ b. Ferec isimli cemaat lideri, bölgeye yeni atanan Fâtımî valisinin vergilerini artırma talebine karşı Fâtımî sarayından olaya müdahale etmesini arz etmektedir. Cemaat lideri, Taberiye'de Yahudi cemaatinden malî durumuna göre bazılarının 5, bazılarının ise 10 dirhem ödediğini; Hayberli olduğunu iddia edenlerin (Hayberiyye) ise cizyeden muaf olduklarını söyleyerek vermediklerini belirtmektedir ${ }^{167}$. Dokümanın baş ve son tarafı olmadığı için Fâtımî sarayının yeni valinin icraatına karşı tasarrufunu bilemiyoruz ${ }^{168}$.

Filistin ve Mısır'daki Hayber Yahudilerine, Fâtımî halifesi Hâkim'in gayr-1 Müslimlere yönelik bazı düzenlemeleri bağlamında da değinilmektedir. 395/1004 yılının Muharrem ayının on üçünde Fâtımî halifesi idaresindeki gayr-1 Müslimlerin siyah giymeleri ve siyah sarık sarmalan konusunda bir emir çıkarmışt. Ancak halifenin Hayber Yahudilerini bu uygulamadan muaf tuttuğu belirtilir ${ }^{169}$. Aynı halife 403/1012-1013 yılında da benzer bir emir çıkarmıs, Yahudi ve Hıristiyanların siyah taylasan ve sarık sarmalarını emrederek ata binmelerini yasaklamasına rağmen bundan Hayberlileri yine muaf tutmuştu ${ }^{170}$.

${ }^{167}$ Gil, “638-1099] "המסים בארץ ישראל בתקופת הכיבוש המוסלמי הראשונה "ha-Masim beErets Yisracl bi"T kufat ha-Kivuş ha-Müslimi ha-Rişona (634-1099)" [illk İslamî Dönemcle (6381099) Filistin'de Vergi], Tsiyon 45 (1980), s. 275. Dokümanın Arapça metni ve İbrânîccye tercümesi için bky. 284-285. Doküman, Gil'in bir başka çalışmasında tekrar neşredilmiştir. Bkz. Gil, Erets Yisrael, II, 453-454 (249. Doküman).

${ }^{168}$ Dokümandan anlaşıldığı kadarıyla Fâtımîler döneminde Taberiye Yahudileri cizyclerini "adam başı" değil de, "müşterek" olarak ödemekte idiler. Yahudilerden cizye vergisi ban yerlerde devlet tarafindan toplansa da çoğunlukla bu işle cemaat temsilcileri görevlendirilirdi. Filistin bölgesinde müştcrek cizyc konan Kudüs ve Taberiye gibi yerlerde vergiler genelde cemaat liderleri tarafindlan toplanırd. Ancak bunun dışında şahıs başı takdir edilen cizyeleri ise her Yahudi bizzat şchir kadısına öderdi. Bkz. Moshe Gil, "The Exilarchate", The Jews of Medieval Islam, Community, Society and Identity, ed. Daniel Frank, E.J.Brill: I ciden-New YorkKöln 1995, s. 46.

${ }^{169}$ Yahya b. Saîd el-Antakî, Tarihül'-Antakî, nşr. Ömer Abdüssclam Tedmurî, 'Trablus 1990. s. 256; İbn Hallikân, Vefeyâtü'l-A'yân, nşr. İhsan Nbbas, Dârü's-sikafe: Bcyrut 1968, V, 293: 1' Halife Hakim'in gayr-1 Müslimlerle ilgili düzenlemelerinin detayları için bkz. Makrizi, el-Hztatu'l-Makriziyye (Kitâbü'lMevâiz ve'l-'Itibâr bi Zikr'l-Hutat ve'l-Âsâr), Kahire [t.y.], II, 495; İbn Tağriberdî, en-Nüicûmü'zZahire fi Müluki Misr ve'l-Kahire, Mısır [1.y.], IV, 177-178.

${ }^{170}$ Yahya b. Saîd cl-Antakî, s. 295. 
Hayber Yahudilerine Abbasîlerin başkenti Bağdat'ta da rastlanmaktadır. XI. asırda Hayber Yahudisi olduğunu ileri süren bir topluluk, ellerinde bulunan, Hz. Peygamber'in kendileri için Hz. Ali'ye yazdırdığı ve bir grup sahabînin de şahit olarak isimlerinin geçtiği bir belgeyi (Kitâbü Resûlillâh) göstererek cizyeden muafiyet talebinde bulunmuşlardı. Halife Kâim'in veziri reîsü'r-rüesâ Ebü'l-Kâsım Ali b. Hasen ${ }^{171}$, belgeyi Hatîb el-Bağdadî'ye (392-463/1001-1070) göndererek gerçek olup olmadığını sormuştu. Belgeyi inceleyen Hatîb el-Bağdadî şahit olarak gösterilen Muaviye'nin Mekke fethinde (Hayber fethinden sonra) Müslüman olduğunu, Sa'd b. Muâz'ın ise Kureyzaoğulları savaşında (Hayber'den iki sene önce) şehit olduğunu belirterek belgenin tamamen sahte/düzmece (müzevver) olduğunu rapor etmiş$\mathrm{ti}^{172}$.

Bağdat'taki Hayber Yahudileri ile bir bilgi de Kitâbül-Havâdis isimli yıllık tarzında yazılan bir eserde ${ }^{173}$ yer almaktadır. 654/1205 yılı hadiscleri arasında o yıl Dicle'nin taştığı ve halkın çoğunun büyük zarar gördüğü kaydedilmiştir. Su taşkınından korunmak için Yahudilerle Müslümanlar bir araya gelerek bentler yapmışlar; ancak bu bentlerden bazı insanların arazileri zarar görmüş ve Yahudilerle tartısmışlardı. Tartışma büyüyünce Yahudiler silahlarını çekip "Ey Hayberliler!" (Yâ Âl-i Hayber) diyerek dindaşlarını yardıma çağırmışlardı. Bunun üzerine olaya müdahale eden güvenlik güçleri Yahudilerden bazılarını gözaltına almış, bazılarını ise dayak atarak cezalandırmışlardı. Güvenlik güçlerinin daha sonra Yahudileri “...Silah çekip Hayberlileri yardıma çağımanın cezası" budur diyerek bir daha yapmamaları konusunda uyardıkları belirtilir ${ }^{174}$.

Kaynaklardan anlaşıldığı kadarıyla Hayberlilerin cizyeden muafiyet talebi Mısır, Filistin ve Bağdat'la sınırlı değildi. Cizyeden muaf olduklarına dair ellerinde bir belge olduğu iddiası Dimaşk'ta yaşayan Hayberliler tarafindan da dile getirilmiştir. Hz. Ali, Sa'd b. Muâz ve bazı sahabenin şahit

171 397/1006 yilında doğan Ebü'l-Kâsım Ali b. Hasen, "Rcîsü'r-rücsâ" olarak anılıđd. Abbasî sarayında uzun müddet kâtiplik yaptıktan sonra Halifc Kâim zamanında vezirliğe getirilmişti. Bkz. Yâkût, Mu'cemü'l-Udebâ, Dâru'l-Mc'mûn li't-Türâs [t.y.], III, 18; Zchclŝ, Siyeru A'lâmi'n-Nübelâ, XVIII, 216-217.

172 İbnü'l-Cevîi, el-Muntazam fí Târihi'l-Ümem, Dâru Sâdır: Beyrut 1358, VIII, 265; Yâkût, Mu'cemül'-Udebâ, III, 1819; Zehcbî, Siyeru A'lâmi'n-Nübelâ, XVIII, 280; Sübkî, Tabakâtü's-

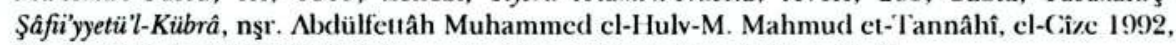
IV, 35; Safedî, el-Vâfi bill-Vefeyât, nşr. H. Ritter, Wiesbaden 1962, 1, 44-45.

${ }^{173}$ Escrde 626-700/1228-1301 tarihleri arasındaki olaylar anlatılııı̧ır.

${ }^{17-4}$ Kitâbül'-Havâdis: el-Havâdisü'l-Câmia ve't-Tecâribü'n-Nâfia fíl-Mieti's-Sâbia, nşr. Beşşar Avvâd Ma'ruf-Imâd Abdüssclam Raûf, Beyrut: Dârü'l-Garbi'l-Islamî, 1997, s. 334. 
olarak kaydedildiği belgeyi gösteren bir grup Yahudi, kendilerinin cizyeden muaf tutulmasını talep etmişlerdi. Belge, İbn Teymiyye'ye (ö. $652 / 1254)$ gösterilmiş, İbn Teymiyye de belgenin sahteliğini on ayı gerekçe ile ortaya koymuştu ${ }^{175}$. Benzer şekilde 701/1301 yllında yine Dimaşk'ta Hayberli olduğunu iddia eden bazı Yahudilerin de Hz. Ali tarafindan yazıldığını iddia ettikleri düzmece bir belge ile cizyeden muafiyet talebinde bulundukları belirtilir ${ }^{176}$.

Hayber, cizye ayetinin nazil olmasından önce fethedildiği (7/628) için Yahudilere cizye konmamıştu. İki yıl sonra inen (9/630) cizye aycti ile belki cizye de konabilirdi; ancak Hz. Peygamber'in böyle bir takdirde bulunmadığı anlaşılmaktadır. Belki de Hz. Peygamber yaptıkları hizmetleri karşılığı (topraklanı yarıcılık usûlü ile ekme) kendilerine cizye takdir etmemişti. $\mathrm{Hz}$. Peygamber'in bu uygulaması sonraki iki halefi (Hz. Ebû Bekir ve Ömer) tarafindan da devam ettirilmiştir. Ancak Hz. Ömer'in hilafetinde yerlerinden çıkarılınca kendilerine yeni bir statü tanındığı; o güne kadar cizyeden muaf tutulan bu Yahudilerden cizye alınmaya başladığı anlaşılmaktadır. Değişik şehirlerde yaşayan Hayber Yahudilerinin ellerindeki düzmece belgeleri göstererek bu tür istekleri artmıs olmalı ki, bunların cizye ile ilgili durumuna hukuk kitaplarında özellikle yer verilmiştir. Mâverdî ve İbn Kayyım'in eserlerinde Hayber Yahudilerinin (Hayâbire) cizyesi ile ilgili kesin hükmün şu olduğu belirtilmiştir: Hayber Yahudileri de diğer (gayr-ı Müslim yahut Yahudi)ler(i) gibidirler. Diğerleri gibi onlar da cizye ile mükelleftir. Her iki müellif de bu konuda hukukçuların görüş birliğinde olduklarını belirtir ${ }^{177}$. Ancak uygulamada Abbasîler döneminde Hayberli olduklarını söyleyen Yahudilerden cizye alındığı, Fâtımîler tarafindan ise cizyeden muaf tutuldukları anlaşılmaktadır. Yukarıda Halife Hâkim'in Hayberlileri gayr-ı Müslimlerle ilgili bazı düzenlemelerden muaf tutması, Taberiye'de Hayberli Yahudilerin müşterek cizyeye iştirak etmemeleri bunu göstermektedir. Bu durum geç dönemlere ait bir Yahudi kroniğinde de dile getirilmiştir. Mısıh Yahudi tarihçi Sambari (1640-1703) Divrey Yosef isimli kroniğinde Rehabîlerin soyundan gelen ve $\mathrm{Hz}$. Ömer zamanında sürülen Hayberlilerin cizyeden muaf tutulduğunu ve bunun Müslüman hukukçular tarafindan da bu şekilde değerlendirildiğini belirtir ${ }^{178}$.

175 İbn Kayyım, Zadül-Mead, nşr. Şuayb Arnavud-Abdülkadir Arnavud, Bcyrut 1981, III, 152-153.

${ }^{176}$ Bk\%. İbn Kayyım, Ahkamu Ehli'z-Zimme, I, 53.

${ }^{177}$ Bkz. Mâverdî, Ahkâmü's-Sultâniyye, Beyrut 1985, s. 183; İbn Kayyım, Ahkâmu Ehli'z-Zimme, I, 51-54.

${ }^{178}$ Sambari, Divrey Yosef, s. 97. 


\section{Hayber Yahudileriyle Yapıldığı İddia Edilen Anlaşma Metni}

İbn Kesîr, Hayberli Yahudilerin 300/912'lü yıllardan itibaren ellerindeki düzmece bir belgeyi göstererek $\mathrm{Hz}$. Peygamber'in kendilerini cizyeden ebedî olarak muaf tuttuğunu iddia etmeye başladıklarını; hatta bazı ulemanın bu belgeyi gerçek zannettiğini belirtir ${ }^{179}$. Aynı müellif Şafî̂ ulemasından Ebû Ali Hayrûn'un belgenin tamamen düzmece olduğunu ortaya koyduğunu; İbnü'l-Müslime'nin (425/1033) de ${ }^{180}$ belgenin sahteliğine dair müstakil bir risale yazdığını kaydeder ${ }^{181}$.

İslâm kaynaklarında Yahudilerin düzmece bazı belgelere sahip oldukları belirtilmekte ise de bu belgelerin metinleri verilmemektedir. Ancak $\mathrm{Hz}$. Peygamber'in Yahudileri cizye ve bazı yükümlülüklerden muaf tuttuğuna dair bir belge Geniza dokümanları vasıtasıyla günümüze ulaşmıştır. Cambridge Üniversitesi'ndeki Geniza tasnifinde [T.S. 8 Ka. I] kayıth Yahudice-Arapşa bu belge, ilk kez Hirschfeld tarafindan bir süreli yayında neşredilmiştir. Belge 3 kısımdan oluşmaktadır:

I. Hayber'e sürülen Benî Nadîr Yahudilerinin reisi Huyey (belgede Hunay) b. Ahtab'ın torunlarından olan, ancak ihtida ettiğini söyleyen bir Yahudinin, dedeleri Hayber Yahudilerine Peygamberimizin emriyle Hz. Ali tarafından bir anlaşma metni yazıldığının belirtildiği giriş (hutbe).

II. Maknâ ve Hayber Yahudilerine yazılan ve Hanînâ'ya tevdi edilen; Yahudilere tanınan hakların yer aldığı asıl kısım.

III. Hz. Peygamber'in şeceresi.

Girişte (I. kısım) Huyey b. Ahtab'ın torunlarından, ihtida ettiğini söyleyen bir Yahudi, önce kendinin Yahudilerden berî (uzak) olduğunu belirttikten sonra, Müslümanlara $\mathrm{Hz}$. Peygamber'in Hayberlilere yazdığı sözde anlaşmayı hatırlatmakta ve Müslüman bir dindaşlaıı olarak anlaşmada taahhüt edilen hususlara uyulmasını tavsiye etmektedir. Bu kısımda Huyey b. Ahtab'ın isminin Hunay şeklinde yanlıs verilmesinden başka, büyük bir tarihî bilgi hatası da yapılmıştır. O da Peygamberimiz'in eşi Hz. Safiye'nin, Huyey b. Ahtab'in annesi olarak verilmesidir. Oysa Hz. Safiye, Huyey b. Ahtab'ın annesi değil, kızıdır ${ }^{182}$.

179 İbn Kesîr, IV, 219.

${ }^{180}$ Adı, Ebü'l-Ferec Ahmed b. Muhammed olan bu alim, döneminde Bağdat'ın en iyi hadîsçilerinden biri olup 425/1033 yılında yetmiş yaşında iken vefât etmiştir. Bkz. Zeheb̂̀, Siyeru A'lâmi'n-Nübelâ, XVIII, 215.

181 İbn Kesîr, IV, 220.

${ }^{182}$ Bkz. Vâkıdî, II, 673-674; İbn Sa'd, VIII, 120, 123. 
Belgenin esasını oluşturan II. Kısımda, Maknâ ve Hayber Yahudilerinin bu anlaşma ile can, mal ve dinlerinin garanti altına alındığı ve anlaşmanın dünya ayakta durdukça yürürlükte olacağı ifade edilmiştir. Bu kısımda Yahudilere verilen imtiyazların sebebi, Peygamberimiz'in eşi Hz. Safiye olarak gösterilmektedir. Buna göre Hayberliler cizye ve toprak vergisi (öşür) dahil her türlü vergiden muaf tutulmuşlardır. Onlar her ne sebeple olursa olsun savaşa gitmeye zorlanmayacak; yardıma ihtiyaç duyduklarında kendilerine yardım edilecektir. Hayberliler ya kendilerinden bir idareciyle ya da Resûlullah'ın ehl-i beytinden biri tarafindan yönetilecektir. Anlaşma ile Yahudilerin saçları ve ayakkabılarının kesilmemesi, renkli elbiseler giymelerine, ata binmelerine ve silah taşımalarına engel olunmaması ve cenazelerinin defnedilmesine imkân tanınması teminat altına alınmıştır. Hayberliler diğer gayr-1 Müslim tebaadan farklı ve onlardan da üstün bir konumda kabul edilmiştir: "(Diğer) zimmet ehlinin konumuna düşürülmeyeceksiniz." Hayberli bir Yahudi kasten bir Müslümanı öldürmesi halinde, Müslümanla eşit hukukî muamele görecek; kendileriyle yapılan savaş sırasında öldürdükleri Müslümanlar için kendilerine ne kısas uygulanacak ne de onlar diyet ödeyeceklerdir. Vesikanın bu kısmı, içinde barındırdığı şartlara riayet etmeyenlerin üzerine Allah'ın, meleklerin ve insanların lânetinin olması bedduası ve cehennem azabı tehdidi ile bitmektedir.

Belgenin son kısmında ise Hz. Peygamber'in Adem'e (a.s) kadar bir şeceresi verilmiştir. Hz. Peygamber'in Adnân'a kadar varan nesep zinciri, İslâm kaynaklarındaki rivayetlerle de örtüşmektedir. Adnân'dan sonra Ud'la başlayıp İsmail ve İbrahim peygamberlere kadar verilen zincir, bazı isimler hariç, İslâm kaynaklarında da verilmektedir. Ancak İslâm kaynaklarında Hz. Peygamber'in Ûd'la İbrahim arasındaki dedelerine dair bilginin, ehl-i kitap kaynaklı olduğunu belirtmek gerekir ${ }^{183}$. Çünkü Hz. Peygamber kendi nesebi ile ilgili Adnân'dan sonrasına dair herhangi bilgi vermemiştir ${ }^{184}$. Bu sebeple İslâm kaynaklarında soy kütüğünün Adnân'a kadar uzanan kısmı güvenilir bulunarak kaydedilmiş, ondan sonrası $\mathrm{Hz}$. Peygamber'in de işaretiyle yaygınlık kazanmamışıır ${ }^{185}$. Belgede Hz. Peygamber'in İbrahim'den (a.s) Adem'e (a.s) kadar ki nesep zincirinde ise tama-

${ }^{183}$ İbn Sa'd'ın konuyla ilgili verdiği bilgi için bkz.. I, 57-58.

184 Ensâlb kitaplarında Hz. Peygamber'in nescbini Adnân vcya Uded'c kadar saydığı; daha sonra ise sustuğu rivayet edilir. Urve b. Zübeyr, Hz. Peygamber'in Ma'ad'tan sonraki dedelerini bilen herhangi bir nesep aliminin olmadığını söyler. Bkz. İbn Sa'd, I, 58; Belâzurî, Ensâb, I, 12; Müberred, Nesebü Adnân ve Kahtân, nşr. Abdülazîz el-Meymenî, Kahire 1936, s. 1. Ilz. Peygamber de nesebini $\Lambda$ dnân'dan sonrasına çıkaran nesepçilerin bilgisinin doğru olmadığını belirımiştir. Bkz. Belâzurî, Ensâb, I, 12; Müberred, Nesebü Adnân ve Kahtân, s. 1.

${ }^{185}$ Bkz. Mustafa Fayda, “Adnân”, DLA, I, 391-392. Adnânîler menşe olarak Arap olmayıp sonradan Araplaşıkları için Arab-ı Müsta'ribe adıyla anılmışlardır. Bk\%. Hakkı Dursun Yıldız, "Arap: Tarih", DIA, III, 273. 
men Tevrat esas alınmıştır. Ancak belgedeki nesep zincirinde Tevrat'taki sıralamadan iki kişi, Peleg'le Arbahşad arasındaki Şelah ve Eber atlanmış$\operatorname{tir}^{186}$. Hz. Adem'den de, topraktan yaratıldığına işaret için, "İbnü't-Türâb" şeklinde bahsedilmiştir.

Hamidullah, Geniza'daki bu metnin Hayberliler tarafindan uydurulduğu, Maknâ Yahudilerinin ise sonraki zamanlarda metne dahil edildiği görüşündedir ${ }^{187}$. Kaynaklarda Hz. Peygamber'in Hayber Yahudileriyle anlaşma metnindeki hükümleri ihtiva eden herhangi bir anlaşmasından bahsedilmemektedir ${ }^{188}$. Ancak bu belgedeki bazı hükümler, İslâm kaynaklarında Maknâ Yahudileriyle yapıldığı belirtilen anlaşma metinlerinde de yer almaktadır. Anlaşma metninde Yahudilerin cizye ve toprak vergisi (ösür) dahil her türlü vergiden muaf tutulduğu bilgisi ile "Yahudilerin ya kendilerinden bir idareci ya da Resûlullah'ın ehl-i beytinden biri tarafindan yönetileceği" maddesi İbn Sa'd ve Belâzurî'de de yer almaktadır ${ }^{189}$. Bunların haricinde Yahudilerin Allah'ın ve Resûlünün zimmetinde olduğu, kendilerine zulüm ve haksızlık yapılmayacağı ifadeleri ise hem İslam kaynaklarında hem de Geniza'daki bu dokümanda dile getirilen müşterek hususlardır.

Genizadaki belgeyi neşreden Hirschfeld, hicretin ilk asıında Hz. Peygamber için "salât ve selâm" ifadelerinin kullanılması, belgede sahabenin önde gelenlerinden üçünün isminin olması ve ilk dönem kaynaklarda $\mathrm{Hz}$. Ali'nin "Ali b. Ebî Tâlib" şeklinde değil de daha çok "Ali b. Ebû Tâlib" şeklinde telafuz edilmesinden hareketle belgenin uydurma değil gerçek olduğu ve her türlü sıhhati de taşıdığı görüşündedir ${ }^{190}$.

Ancak tarih, dil ve muhteva açısından düşünüldüğünde, belgenin uydurma olduğunu anlamak zor olmayacaktır. Vesikanın sahte olduğunu her şeyden önce tarihi göstermektedir. Belgede anlaşmanın hicretin 5. yılında (626) Ramazan'ın üçünde yazıldığı belirtilmektedir. Oysa Hayber hicrî 7 (628), Maknâ ise hicrî 9. yılda (630) fethedilmişti ${ }^{191}$. Sözde anlaşma met-

${ }^{186} \mathrm{Bkz}$. I. Tarihler, $1 / 24$.

${ }^{187}$ Hamidullah, İslam Peygamberi, I, 608.

${ }^{188}$ Hamidullah Hz. Peygamber'in Hayberlilere yazdığı iki mektubu el-Vesâik' inda neşretmiştir. Bunlardan biri, $\mathrm{Hz}$. Pcygamber'in Hayberlileri kendisine inanmaya ve tâbi olmaya çağırdığı davet mektubudur. Bkz. Hamidullah, el-Vesâiku's-Siyâsiyye, s. 37-38 (15. Vesîka). Hz. Pcygamber mektubunda kendi kitaplarında Hz. Peygamber'in sıfatlarını ve özclliklerini bilen Yahudilere (Bu bilgi İbn Sa'd'da geçmektedir: I, 159-160) bunu hatırlatmıştır. Hayberlilere gönderilen diğer mektup ise Hayber'de şehit edilen Abdullah b. Sehl'in diyeti ile ilgilidir. Bkz. Hamidullah, el-Vesâiku's-Siyâsiyye, s. 39 (16. Vesîka).

${ }^{189}$ Bkz. İbn Sa'd, I, 277; Bclâzurî, Fütûh, s. 81 .

${ }^{190}$ Bkz. Hirschfeld, "The Arabic Portion of the Cairo Genizah at Cambridge", JQR, Old Series XV (1903), s. 174.

${ }^{191}$ Bkz. Belâzurî, Fütûh, s. 33 (Hayber); s. 81 (Maknâ). 
ninde Hayber ya da Maknâ Yahudilerinden İslam'a tabi olanlara verilecek atânın, Hz. Peygamber'in ailesine verilen atânın dörtte biri kadar olacağı ifade edilmiş ve bunun da Kureyş'e ödendiği sırada verilmesi belirtilmiştir. Oysa atıyye uygulaması İslâm tarihinde ilk kez Hulefâ-yı Râşidîn zamanında Hz. Ömer'in divan teşkilâtını kurmasından sonı başlamışıı' ${ }^{192}$. Hayberlilerin saç, elbise, ayakkabı gibi giyim-kuşamlanı ile ata binme ve silah taşımaları gibi konular ise, ilk dönemlerin değil, sonraki dönemlerin bir konusudur. Çünkü Hz. Peygamber ve Hulefâ-yı Râşidîn zamanında gayr-1 Müslimlerin elbiseleriyle ilgili herhangi bir sınırlama ve düzenlemeye rastlanmaz. Hatta kendilerine zimme verilen gayr-1 Müslimler, dinî ya da kültürel olarak benimsedikleri elbiselerden istediklerini giyme özgürlüğüne sahiptiler ${ }^{193}$. Gayr-1 Müslimlerin elbiseleri ve sosyal hayatlarıyla ilgili ilk düzenleme Halife Hârunürreşîd tarafından yapılmıştır. 191/806 yılında gayr-ı Müslimlerin Müslümanlardan farklı giyinmeleri ve başka binitlere binmeleri konusunda bir emir çıkarılmışt ${ }^{194}$. Abbasî halifesi Mütevekkil dönemine kadar gayr-1 Müslimlerin ata binmeleri ve Abbasîler gibi siyah renkli elbiseler giymelerine herhangi bir sınırlama yoktu ${ }^{195}$. Halife Mütevekkil 235/849 yılında gayr-1 Müslimlerin giydikleri dürrâ'a ve kabâ üzerine taktıkları taylasanların bal renkli olmasını emretmişti ${ }^{196}$. Sonraki dönemlerde kılık kıyafetle ilgili benzer düzenlemeler Halife Muktedir (296/908) ve Halife Kâim (429/1037) tarafindan tekrar duyurulmuştur ${ }^{197}$. Bu tür uygulamaların son örneği ise Fatımî halifesi Hâkim bi-Emrillâh tarafindan yürürlüğe konmuştur ${ }^{198}$. Zimmilerin Müslümanlardan farklı elbiseler giymesi meselesine Kur'ân ve sünnette hiç değinilmemiştir. Gayr-1 Müslimlerin elbise meselesi sosyal, siyasî ve zamana bağlı bir durum olup sonraki dönemlerde ortaya çıkmış ve zaman zaman bir takım gerekçelerle yürürlüğe konmuştur ${ }^{199}$. Illk dönemlerde gayr-1 Müslimlerin kılık kıyafeti ile ilgili herhangi bir düzenlemeden bahsedilmez; ancak sonraki dönemlerde ihdas

${ }^{192} \mathrm{~Hz}$. Ömer'in Divan Teşkilâtını kurması ve atıyyeleri dağıtması için bkz. Fayda, "Hz. Ömer'in Divan Teşkilatı", Doğuştan Günümüze İslam Tarihi, İstanbul 1992, II, 140-176.

193 İbn Kayyım, Ahkâmu Ehli'z-Zimme, II, 756.

194 Taberî, Târîhu't-Taberí, nşr. Muhammed Ebu'l-Fadl İbrâhîm, Beyrut 1967, VIII, 324; İbnü'l-Esîr, I, 206. Ancak halifenin bu emri, kısa bir süre sonra ozcl tabibi Cebrail b. Buhtîşu'nin teşcbbüsüyle geri aldığı belirtilir. Bkz. M.M. Nhsan, Social Life under the Abbasids, London 1979, s. 61-61.

${ }^{195}$ Bkz. Saîd b. Batrîk, et-Tarihü'l-Mecmû' ale't-Tahkîk ve't-Tasdîk, nşr. L. Chcikho, Bcyrut 1909 , s. 59.

${ }^{196}$ Ya'kûbî, Târih, II, 487; Tabcrî, VIII, 324; İbnü'l-Esîr, VII, 52.

197 İbnü'l-Cevzî, el-Muntazam, VIII, 96-97, 171.

${ }^{198}$ Hakim'in uygulamaları için bkz. Makrizi, Httat, II, 495.

${ }^{199}$ Hamidullah, "íslâmda Devletler Hukuku", trc. Abdülkadir Şener, (AÜIF) İslam İlimleri Enstitüsü Dergisi 3 (1977), s. 299. 
edilen kılık kıyafet düzenlemeleri de ya Hz. Ömer'e ya da Ömer b. Abdülaziz'e irca edilmiştir ${ }^{200}$.

Hamidullah, Abbasî halifesi Hârunürreşîd zamanında yapılan düzenlemelerin İbn Sa'd'da (ö. 230/884) yer alan sözde anlaşma metninin; Mütevekkil zamanında yapılan düzenlemelerin ise Belâzurî'deki (ö. 279/892) metnin uydurulmasına sebep olduğu kanaatindedir ${ }^{201}$. Hakikaten de Belâzurî, kitabına aldığı anlaşma metninin Yahudilerin elinde bulunan bir nüshadan istinsah edildiğini belirtir ${ }^{202}$. Hamidullah Hirschfeld'in neşrettiği Geniza metninin ise Fatımî halifesi Hâkim'in gayr-1 Müslimlerle ilgili düzenlemelerinden sonra tertip edildiği düşüncesindedir. Uydurmanın asıl maksadı Şî̂lerin Yahudilere karşı fanatik duygularını ortadan kaldırmaya yöneliktir ${ }^{203}$. Geniza'daki metinde yer alan şahitlerin Ammâr b. Yâsir, Selmân-ı Fârisî ve Ebû Zer el-Ğıfârî gibi Şîlerce farklı bir konuma oturtulan sahabîlerden seçilmesi de dikkat çekicidir ${ }^{204}$.

Hirschfeld'in neşrettiği bu dokümanın Hayber (ve Maknâ) Yahudilerinin cizyeden ve gayr-1 müslimlerle ilgili diğer düzenlemelerden muaf tutulduğunun bahsedildiği II. kısmı merhum M. Hamidullah tarafından neşredilmiştir. Hamidullah sadece vesikaları neşrettiği için belgenin ilk kısmı (giriş/hutbe) ile belgenin sonundaki Hz. Peygamber'in nesebinin Adem'e (a.s) kadar çıkarılan bölümü (III. kısım) el-Vesâik'a almamıştır. Biz Hamidullah'ın eserine aldığı (II.) kısım da dahil Hirschfeld'in neşrettiği belgenin Yahudice-Arapça (İbranî harfleri ile yazılmış Arapça) tam metni$\mathrm{ni}^{205}$, bunun Arap harfleriyle yazılışı ile Türkçe tercümesinin tamamını burada vermek istiyoruz".

${ }^{200}$ Ebû Yûsuf, gayr-1 Müslimlerin Müslümanlardan farklı giyinmeleri konusunu $\mathrm{Hz}$. Ömer'c irca eder. Bkz. Kitâbü'l-Harâc s. 127. Konuyla ilgili değerlendirme için bkz. A.S. Tritton, The Caliphs and their non-Muslim Subjects, London 1930, s. 116 vd.; Mustafa Fayda, $\mathrm{Hz}$. Ömer Zamanında Gayr-t Müslimler, s. 174-175; Levent Öztürk, İslâm Toplumunda Htristiyanlar, İstanbul 1998, s. 244-246.

${ }^{201}$ Hamidullah, Islam Peygamberi, I, 608.

202 "Bir Mısırlı bana, Maknâ halkna yazılmı̧ vesikayı, kınnzz deri üzerinde ve yazısı bozuk bir halde bizzat gördüğünü ve aynen istinsah ettiğini haber verdi ve o nüshayı bana aynen yazdrdd." Bkz. Bclâzurî, Fütâh, s. 80.

${ }^{203}$ I Iamidullah, İslam Peygamberi, 1, 608.

${ }^{204}$ Söz konusu sahabîlerin ehl-i beytten sayılması ile ilgili değerlendirmeler için bkz. M. Bahaüddin Varol, Ehli Beyt-Kavramsal Boyut, Konya 2002, s. 87 vd.

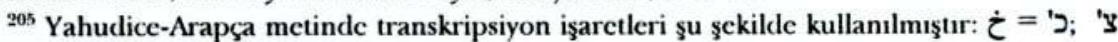
ض=; $=$ '

"Dokümandaki Yahudice-Arapça (İbranî harfleri ile yazılmış Arapça) ve Arap̧̧a metni incelcycrek değerli tenkit, teklif ve tavsiyelerini esirgemeyen Hayfa Üniversitesi (İsrail) Beşerî Bilimler Fakültesi (Faculty of Humanities) İbranî Dili Bölümü (Department of Hebrew Language) öğretim üyesi Dr. Tamar 7ewi Hanım’a teşekkür ederim. 


\begin{tabular}{|c|c|c|}
\hline 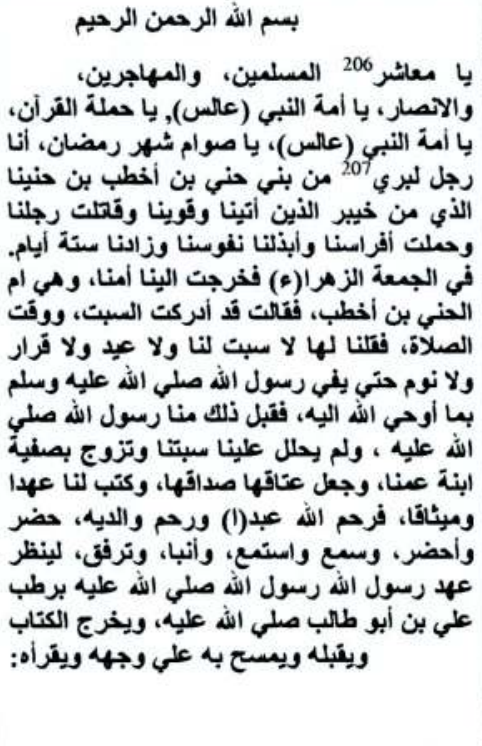 & 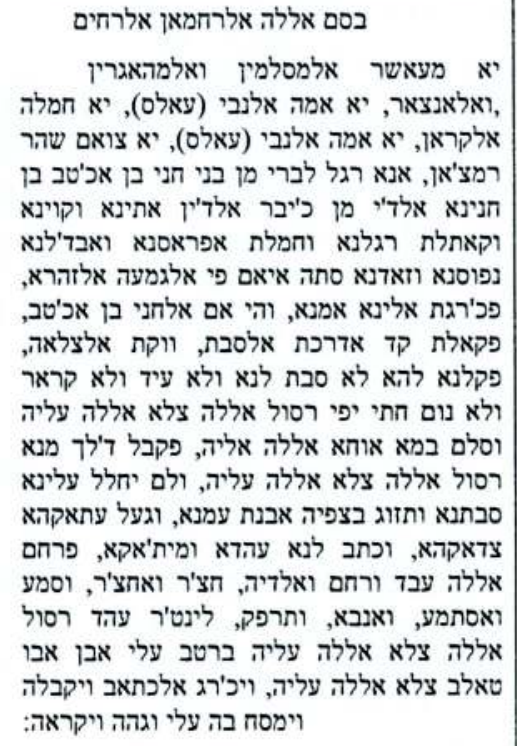 & (I) \\
\hline 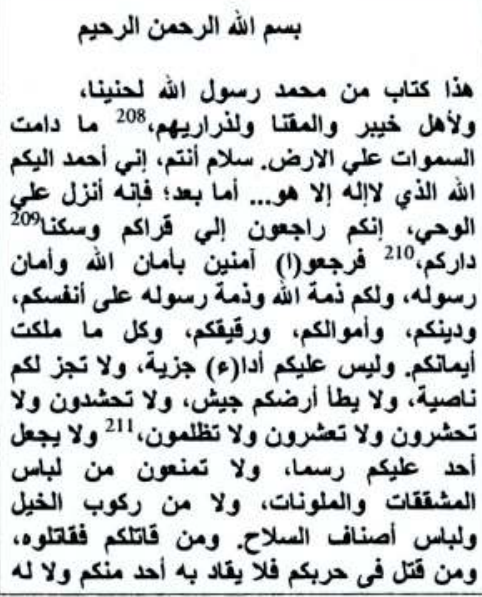 & 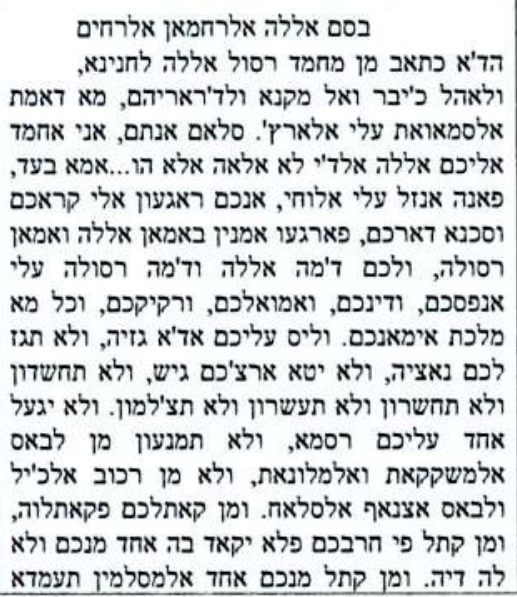 & (II) \\
\hline
\end{tabular}

${ }^{206}$ Hirschfeld'in de "מעאשר" şeklinde okuduğu bu kelime dokümanda Yahudice-Arapça asıl metninde "מגeklinde yer almaktadır.

207.

${ }^{208}$ Burada yazmanın diğer varağı (Verso) başlamaktadır.

${ }^{209}$ Metinde "ي" değil, "l” ile yazılmıştır. Hamidullah" ta ise "ي" ile yazılmıştır.

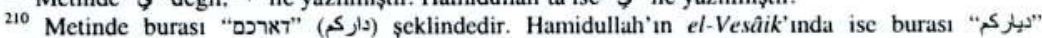
şeklinde okunmuştur.

ולא תצלמון 


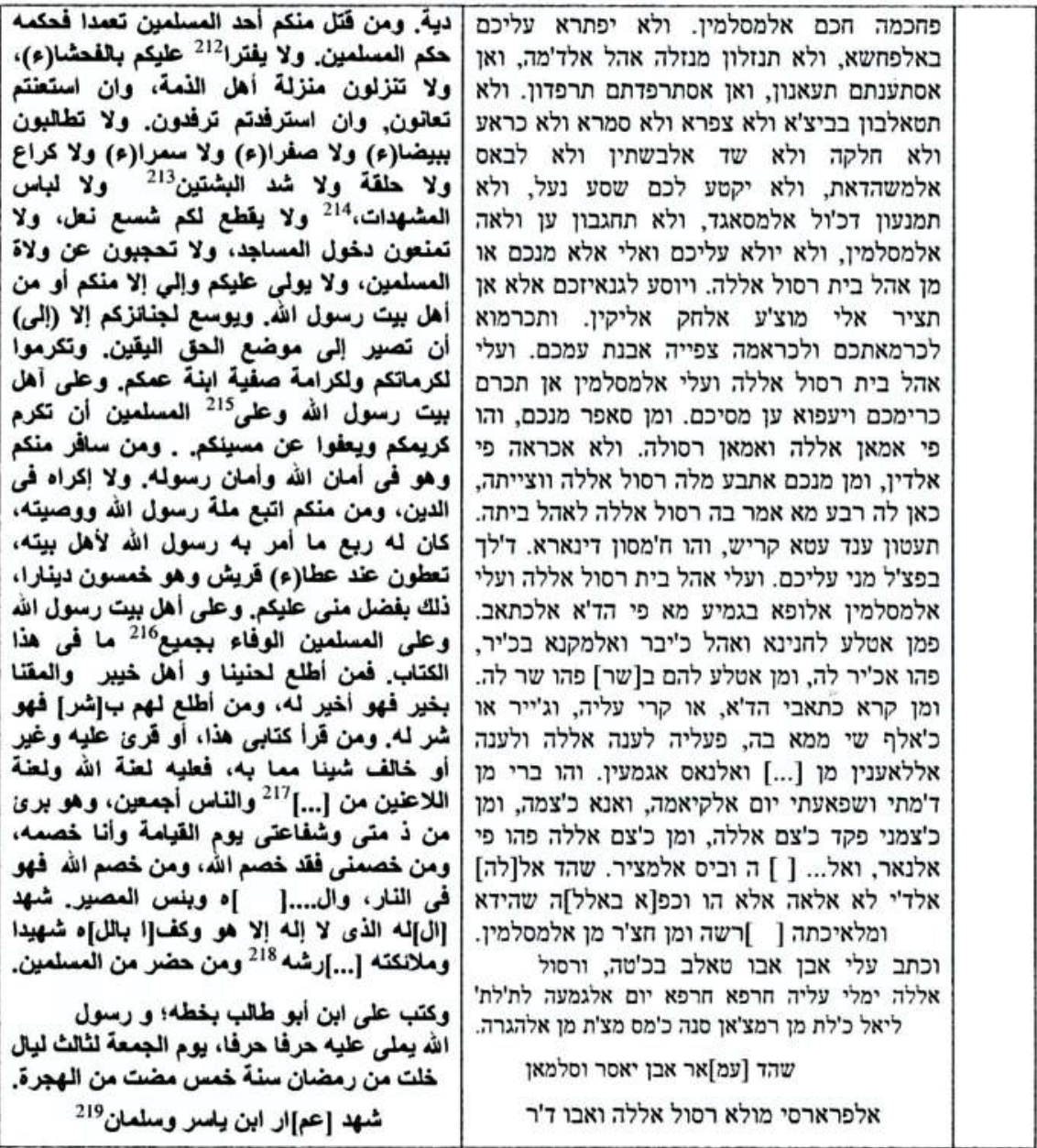

${ }^{212}$ Metinde "ي" değil, “足 ile yazılmıștır. Hamidullah’ta ise "ي" ile yazılmıștır.

${ }^{213}$ Yahudice-Arapça metinde burada "אלבשתין" kelimesi kullanilmıştur. Hamidullah'ta bu kelime

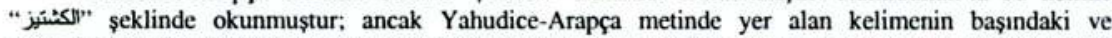

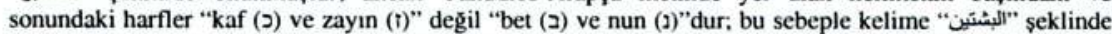
okunmalıdır. Yakın zamanlarda Yahudice-Arapça metinlerdeki kelimelerin okunmasına yönelik hazırlanan bir sözlukte "بشت" kelimesinin "kaftan", "abâ" anlamına geldiği belirtilmektedir. Bkz. J. Blau. A Dictionary of Mediaeval Judaeo-Arabic Texts, The Academy of the Hebrew Language and The Israel Academy of Sciences and Humanities: Jerusalem 2006, p. 42. Bilgiyi veren Dr. Tamar Zewi'ye teşekkür ederim.

214 Hamidullah'ta bu kelime "المنهرات" șeklinde okunmuştur; ancak kelimenin Yahudice-Arap̧̧ası "אלמש(א) הדאתת" olduğundan bu kelimenin "المشهدات" șeklinde olması daha uygundur.

${ }^{215}$ Burada yazmanın diğer varağı (Fol. 2 Recto) başlamaktadır.

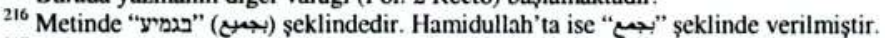

217 Metnin aslında verilmeyen ve bos bırakılan bu yer Hamidullah'ta "...... şeklinde verilmiștir.

${ }_{218}^{218}$ Hamidullah, metinde verilmeyen bu yeri "

219 Burada yazmanın diğer varağı (Verso) başlamaktadır. 


\begin{tabular}{|c|c|c|}
\hline الفرارسى مولا رمول الله وأبو ذري الغنرى. & אלג'פארי. & \\
\hline 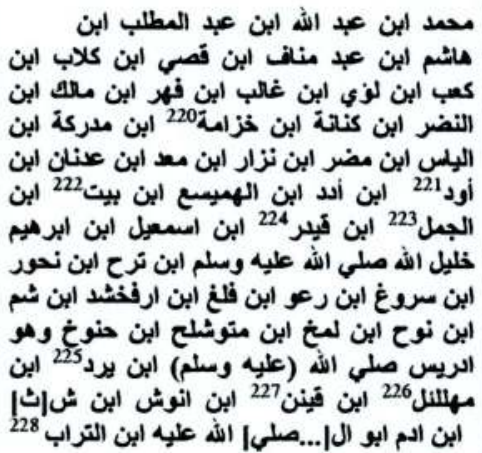 & 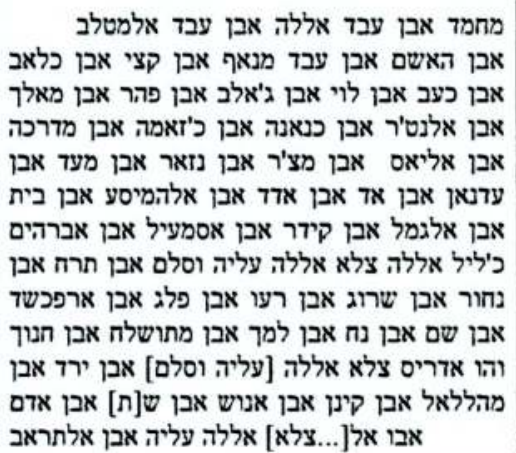 & (III) \\
\hline
\end{tabular}

220 Islam kaynaklannda "خزيمة" olarak gef̧mektedir. Bkz. Zübeyrî. Nesebï Kureyş. nşr. E. Levi Provenf̧al, Kahire 1982, s. 7; Belâzuri, Ensâb, I, 35.

221 Veya "أi". Bkz. Belâzuri. Ensâb, I. 22.

222 Belazuri de Hemeysa'dan sonra Kayder'e atlanmakta ve "بيت" ismi "تبت" seklinde verilmektedir. Bkz. Ensâb, I, 12. Zübeyrí de ise "تلبت" șeklinde geȨnektedir. Bkz. Zübeyrî, Nesebü Kureyș. s. 3.

${ }^{223}$ Ibn Sa'd'da "حمل بن قينر". Bkz. I, 57.

${ }^{224}$ Bu isim Zübeyn'de "ميذار" (Nesebü Kureyș. s. 3); Ibn Sa'd'da ise "ميذر" (1. 56) șeklinde verilmiştir.

${ }^{225}$ 'Zubeyrí' de "بائر" ve "الرالد". Bkz. Nesebü Kureys. s. 4.

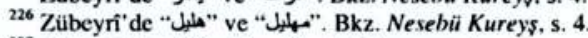

${ }^{227}$ Zübeyrî' de "قنان". Bkz. Nesebü Kureys, s. 4.

${ }^{228}$ Íbn Sa'd'da meşhur nesep alimi İbnù'l-Kelbî'den nakledilen. Tevrat'ın Tekvin (5. bap) ve I. Tarihler kitaplannda (1. bap) verilen nesep zinciri ile de ortüşen bir rivayette $\mathrm{Hz}$. Íbrahim' in (a.s) soyu Âdem'e (a.s) kadar şu şekilde verilmiştir:

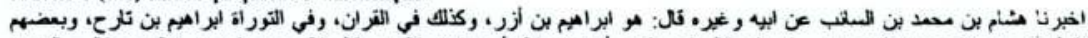

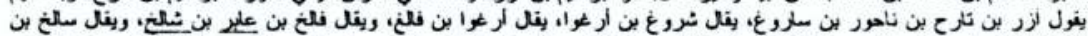

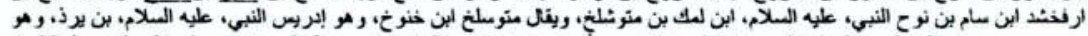

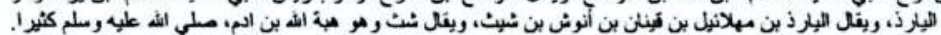

Bkz. İbn Sa'd, I, 59. İbn Sa'd taki bu rivayette belgedeki zincirden farkh, ancak Tevrat'taki bilgiye

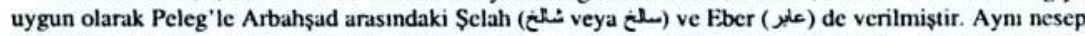
zinciri Zübeyñ' nin kitabına aldığı bir rivayette de yer almaktadır. Bkz. Zübeyrî, Nesebii Kureys. s. 4. 
(I) Rahmân ve Rahîm olan Allah'ın adıyla:

Ey Müslüman, Muhacir ve Ensâr topluluğu! Ey Nebî [a.s] ümmeti! Ey Kur'ân hafizları (Hamele-yi Kur'ân)! Ey Nebî [a.s] ümmeti! Ey Ramazan orucunu tutanlar! Ben, Hayberli Hunay b. Ahtab b. Hanînâ'dan uzak olan bir adamım. Onların üzerine yürüdük ve haklarından geldik. Ayaklarımız savaştı; atlarımız götürdü. Haftanın altı gününde kendimizi ve azığımızı bu yola seferber ettik. Parlak bir Cuma günü annemiz bize geldi. $\mathrm{O}$, Hunay b. Ahtab'in annesidir. (Annemiz) şöyle dedi: Sebt ve ibadet vakti geldi. Ona şunu söyledik: Resûlüllah (s.a.v.) Allah'ın vahyettiğini yerine getirip bizden kabul edinceye ve bize sebti haram kılmayıncaya kadar, bizim için ne sebt ne bayram ne dinlenme ne de uyku vardır. (Resûlüllah) amcamızın kızı Safiye ile evlenmiştir. Onu azat etmiş; azatlığını da mehrine saymışıı ${ }^{229}$; ve bize bir de ahit ve anlaşma yazmıştır. Ali b. Ebûn ${ }^{230}$ Tâlib'in (sallallâhu aleyh) yazdığı, eline alıp öptüğü ve yüzünü sürüp okuduğu, Resûlüllah'ın (s.a.v) bu anlaşmasına bakmak için gelen-getiren, duyan-dinleyen, haber veren ve şefkat gösteren kula ve ebeveynine Allah merhamet etsin.

(II) Rahmân ve Rahîm olan Allah'in adıyla:

Bu, Resûlüllah Muhammed'ten Hanînâ'ya ${ }^{231}$, Hayber ve Maknâ halkı ile onların nesillerine gökler yerin üzerinde durduğu müddetçe ${ }^{232}$ geçerli olacak bir anlaşmadır. Sizler selamette olasınız. Sizin adınıza kendinden başka hiçbir ilâh olmayan Allah'a hamd ederim. Meselenize gelince:

Bu konuda bana bir vahiy indirildi; buna göre sizler köylerinize geri dönecek ve ev[ler]inizde oturacaksınız. Allah ve Resûlünün enânıyla güvenlik içerisinde dönün. Size, dininize, mallarınıza, kölelerinize ve ellerinizin altındakilere (cariyelerinize) Allah ve Resûlünün zimmeti verilmiştir. Cizye verme yükümlülüğunüz yoktur. Zülüfleriniz kesilmeyecektir. Toprağınıza hiçbir ordu girmeyecektir. Orduya sevk edilmeyecek, (savaşmak için) toplanmayacak ve öşür (onda birlik vergi) vermeyeceksiniz. Size asla zulmedilmeyecektir. Sizden kimseye herhangi bir vergi yükü (resm) yoktur. Sizler yırtuk ve renkli elbiseler giyebilecek, atlara binebilecek ve her türlü silahı taşıyabileceksiniz. Kim sizinle savaşırsa, siz de onunla savaşın. Böyle

${ }^{229}$ Bu ifade Mes'ûdî̀de de geçmektedir: .... فأعتقها وجعل عنقها صنداقه ... Bkz. Mcs'ûdî, et. Tenbîh ve'l-İ̧̧râf, s. 256.

${ }^{230}$ Yahudice- $\Lambda$ rapça metinde aynen bu şckildedir.

${ }^{231}$ Hamidullah bu ismi I Iuneynâ şeklincle okumuştur. Bkz. el-Vesâiku's-Siyâsiyye, s. 59. Ancak biz tipik bir Yahudi ismi olduğu için bunu "Hanînâ" olarak okumayı tercih cttik.

${ }^{232}$ Yani kıyametc kadar. 
bir savaş sırasında öldürülenlerden dolayı size kısas cezası uygulanmayacak; sizden diyet de alınmayacaktır. Sizden, bir Müslümanı teammüden öldüren kimse, Müslümanla aynı hükme tabi olacaktır. Size fuhuş iftirasında bulunulmayacaktır. Sizler (diğer) zimmet ehlinin konumuna düşürülmeyeceksiniz. Yardım isterseniz, yardım olunacak; desteğe ihtiyaç duyarsanız destek göreceksiniz. Beyaz, sarı ve esmer(leriniz); yetiştirdiğiniz hayvanlar, zırhla$\mathrm{r}^{\prime} \mathrm{nz}^{233}$ ve (dokuduğunuz) kaftanlar sizden istenmeyecektir. Özel alametli elbiseler giymeyeceksiniz. Ayakkabılarınız ön kısmından kesilmeyecektir. Mescitlere girmekten men edilmeyeceksiniz. Müslüman idarecilerin huzuruna çıkmanıza da engel olunmayacaktır. Sizi, ya içinizden biri ya da Resûlüllah'ın ehl-i beytinden biri yönetecektir. Gideceği yere (mezarlığa) varıncaya kadar cenazeleriniz için geniş yer ayrılacaktır. Kendi şerefiniz ve amcanızın kızı Safiyye'den dolayı ihsan göreceksiniz. Sizin şereflinizi şereflendirmesi ve kötülük yapanlarınızı bağışlaması Resûlullah'ın ehl-i beytine ve Müslümanlara bir vecîbedir. Sizden yolculuğa çıkan biri Allah ve Resûlünün emanındadır. Dinde zorlama yoktur ${ }^{234}$. Sizden Resûlüllah'ın dinine ve vasiyetine uyana, Resûlüllah'ın ehl-i beytine verilmesini emrettiğinin çeyreği vardır. Bu da Kureyş'in atâsının ödendiği sırada size verilir ki, miktarı elli dinardır. Bu, benden size bir ihsandır. Resûlüllah'ın ehl-i beytinin ve Müslümanların bu anlaşmada yazılı olan her şeye uyması üzerlerine bir vecîbedir. Kim Hanînâ'ya, Hayber ve Maknâ halkına iyi davranırsa, bu onun için en iyisidir. Kim de onlara [kötü] davranırsa bu onun için en kötüsüdür. Bu anlaşmayı biri okuduğunda ya da bu anlaşma kendisine okunduğunda, anlaşmadaki bir şeyi değiştirir veya muhalefet ederse, Allah'ın lâneti ve lânetçi $[\ldots . .]^{\prime} i^{235}$ ve bütün insanların lâneti onun üzerine olsun. $\mathrm{O}$ benim zimmetimden ve kıyâmet günü şefaatimden uzaktur ${ }^{236}$. Ben onun

${ }^{293}$ Burada "esmer" hariç, "beyaz", "sarı", "yctiştirdiğiniz hayvanlar" ve "zrrhlarınız" ibaresi

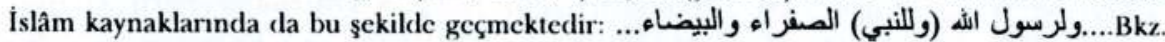
Ilon Sa'd, II, 110; Belâzurî, Fütâh, s. 34; a. mlf., Ensâb, I, 352. وكراعهم وحلثَهم....Bkz. Belâzurî, Fütuh , s. 80. "Beyaz" ve "sarı"dan kasıt, Hayber Yahudilerine teslim şarıları sırasında vermcleri şart koşulan "gümüş" ve "alun"lardır. Ancak "esmer"in neyi ifade ettiğini anlayamadık. "Fsmer"le Hayber'de bol yetişen "hurma"lar kastedilmiş olabilir mi bilmiyoruz. Bilindiği üzere llayber hurması ile meşhurdu ve hurma en önemli ihraç maddesi idi. Bkz. ibnü’lFakîh, Kitâbüll-Büldân, 515; Hemdânî, Stfatu Cezîretill-Arab, I, 131; Albdülazîz b. İbrâhim Ömerî, el-Htref ve's-Stnâ'ât, s. 32, 164.

${ }^{234}$ Bakara, 2/256.

${ }^{235}$ Metnin aslında verilmeyen ve boş bırakılan bu yeri I Jamidullah "I ânetçi melcklerinin..." şcklinde tamamlamışır. Bkz. el-Vesâiku's-Siyâsiyye, s. 61.

${ }^{236}$ Hamidullah, bu ifadenin aslında "Ben omun zimmetinden ve şefaatinden uzağın" şeklinde olması gerektiğini belirterek bunun bilc anlaşmanın sahteliğini göstcrdiğini belirtir. Bkz. elVesâiku's-Siyâsiyye, s. 61. 
hasmıyım. Kim bana hasım olursa, Allah'a hasım olmuştur. Allah'a hasım olanın yeri ise Cehennem'dir. Ve [...]ve orası ne kötü bir dönüş yeridir. Kendinden başka ilâh olmayan [Alla]h şahit olsun. O, melekleri [ve arşı]nı [taşıyan melekler] ve hazır bulunan Müslümanlar şahit olarak yeter.

(Bu anlaşmayı) Ali b. Ebû Tâlib kendi yazısıyla yazdı. Resûlüllah harf harf yazdırdı. (Anlaşma) Hicretin beşinci yılında Ramazan'ın üçüncü gecesinden sonraki Cuma günü yazılmıştır. [Amm]âr b. Yâsir, Selmân elFerârisî ${ }^{237}$ ve Ebû Zerr el-Ğıfârî şahittir.

(III) Muhammed b. Abdullah b. Abdülmuttalib b. Hâşim ${ }^{938}$ b. Abdü Menâf ${ }^{239}$ b. Kusayy ${ }^{240}$ b. Kilâb b. Ka'b ${ }^{241}$ b. Lüeyy b. Ğâlib b. Fihr ${ }^{242}$ b. Mâlik b. Nadr b. Kinâne b. Huzâme ${ }^{243}$ b. Müdrike b. İlyâs b. Mudar b. Nizâr b. Me'add ${ }^{244}$ b. Adnân ${ }^{245}$ b. Üd b. Üded b. Hemeysa' b. Beyt ${ }^{246}$ b. Cemel ${ }^{247}$ b. Kayder b. İsmail b. İbrahim Halîlullah ${ }^{248}$ (sallalâhu aleyhi ve sellem) b.

${ }^{237}$ Metinde Selmân el-Fârisî bu şckilde yazılmıştır.

${ }^{238}$ Kur'ân'da Kureyş süresinde de belirtildiği üzere Peygamberimiz'in bu dedesinin Bizans imparatoru ve Habeş Necaşî ile yaptığı anlaşma neticesinde (îlâf) Kureyş, yazın kuzcy bölgelerine (Suriye-Anadolu), kışın ise Yemen ve Habeşistan'a rahathkla gidlip gelmeye başlamıştur. $\mathrm{Bu}$, Kureyş'in hem tanınmasını sağlamış hem de saygınlığını arırmışı. Bkz. İbn Sa'd, 1, 75 vd.; Hamidullah, "îlaf", DIA, XXII, 63-64.

${ }_{239}$ Mekke'nin yabancilarla olan siyasî ve iktisadî münascbetlerini geliştirerck şehrin itibar ve nüfûzunu sağlam esaslara oturtan ilk kimsedir. Bkz. İbn Sa'd, I, 75; Hamidullah, İslam Peygamberi, I, 32.

${ }_{240}$ Kusayy'in Arap tarihinde önemli bir yeri vardır. Mekke şehrini yeniden inşâ etmiş, Kureyş kabilesini Ka'be etrafina yerleştirmiş, Dâru'n-Nedve'yi kurmuş, Mckke'nin idaresi ve hac işlerinin düzenlenmesi için vazifeler ihdas etmişti. Bkz. Ibon Hişâm, I, 117-119; İbn Sa'd, I, 70-71; Hamidullah, İslam Peygamberi, I, 32.

241 Ka'b'ın Araplar arasında büyük bir saygınlığı vardı. Cuma günlerinde, içinde hutbe olan haftalık bir ibadet (Yevmü'l-'Arûbâ) ihdas etmişti. Ölümü Araplar için takvim başlangıcı kabul edilmiş, Ebrehe'nin Ka'be'ye saldırdığı yıla kadar da bu takvim kullanılmışı. Bk». Belâzurî, Ensâb, I, 41; Hamidullah, İslam Peygamberi, I, 31.

${ }_{242}$ Kurcyş kabilesinin kurucusu kabul edilen Fihr, Kureyş'i birleştirdiğinden dolayı "Cemmâu Kurcyş" olarak da isimlendirilmiştir. Bkz. Belâzurî, Ensâb, I, 39.

${ }^{243}$ Huzeyme.

${ }^{244}$ Me'add'ın Buhtunnasr zamanında (M.Ö. 604-55 I'ler) yaşadığı belirtilir. Bkz. İbn Sa'd, 1, 58; Belâzurî, Ensâb, 1, 22.

${ }^{245}$ Adnân'ın Buhtunnasr zamanında yaşadığı rivayct edilir. Ka'be'yi deri bir örtü ile örtenlerin ilki Adnân'dır. Bkz. Belâzurî, Ensâb, I, 15. Daha fazla bilgi için bkz.. Mustafa Fayda, "Adnân, DIA I, 391-392.

${ }^{246}$ Nebet.

${ }^{247} \mathrm{Hamcl}$ ?

${ }^{248}$ Nescb zincirinde bundan sonra yer alan isimlerde Ahd-i Atîk (Tevrat) esas alınmıştur. Ahd-i Cedîd'te (İncil) Hz. İsa'nın soyu verilirken de Ever ve Şelah hariç, aynı nesep zinciri 
Terah $^{249}$ b. Nahûr ${ }^{250}$ b. Serûğ ${ }^{251}$ b. Reû́ ${ }^{252}$ b. Feleğ ${ }^{253}$ b. Arfahşad ${ }^{254}$ b. Şem ${ }^{255}$ b. Nûh ${ }^{256}$ b. Lameh ${ }^{257}$ b. Metüşelah ${ }^{258}$ b. Hanûh ${ }^{259}$ (ki o, İdrîs s.a.v.'dir) b. Yared ${ }^{260}$ b. Mehelelil ${ }^{261}$ b. Kaynen ${ }^{262}$ b. Enûş ${ }^{263}$ b. Şi $[s]^{264}$ b. Âdem Ebû el[...salla]llâhu ibnü'-t-Türâb.

verilmiştir. Bkz. Luka 3/23. Tevrat'taki bilgiye göre Hz. Ibbrahim, babası yetmiş yaşında iken dünyaya gelmiştir. Bkz. Tekvin, 11/26.

${ }^{249}$ Nahor yirmi dokuz yaşıncla iken oğlu Terah (תרח) doğmuştu. Bkz. Tekvin, 11/24; 11/27; 11/31; I. Tarihler, 1/24. İslâm kaynaklarında Hz. İbrahim'in babasının adı Ấzer'dir. Bkz. En'âm, 6/74; Buharî, "Enbiyâ" 8; íbn Sa'd, I, 59. Âzcrle ilgili detaylar için bkz. A.J. Wensinck, "Âzer", IA, II, 91; Murray Linchtenstein, "lerah", EJd, XV, 1013-1014; Günay Tümer, "Âzer", DIA, IV, 316-317; J. Eiscnberg, "İbrahim”, İA, V/2, 878. $1 / 24$.

${ }^{250}$ Serug otuz yaşında iken oğlu Nahor (נחור) doğmuştu. Bkz. Tekvin, 11/22; I. Tarihler, $1 / 24$.

251 Re'u otuz iki yaşında iken oğlu Serug (שרוג) doğmuştu. Bkz. Tekvin, 11/20; 1. Tarihler,

${ }^{252}$ Peleg otuz yaşında iken oğlu Re'u (רעו) doğmuşlu. Bkz. Tekvin, 11/18; I. Tarihler, $1 / 24$.

253 Tevrat'la Peleg'le (פלג) Arpahşad arasında Şelah ve Eber isimli iki kişi daha vardır. Bkz.

1. Tarihler, 1/24. Ancak bu isimler yukandlaki belgeye alınmamıșır.

${ }^{254}$ Samı'ın oğullar: Elam, Asur, Arpahşad (ארפכשד), Lut ve Aram. Bk\%. Tekvin, 10/22.

${ }^{255}$ Nuh beş yüz yaşında iken oğlu Sam (שם) doğmuşıu. Bkz. Tekvin, 5/32; 6/10.

${ }^{256}$ Lamch yüz seksen iki yaşında iken oğlu Nuh (נ) doğmuştu. Bkz. Tekvin, 5/28. Tevrat'taki bilgiye göre Âdem'den Nuh'a on nesil vardır: Ầlem (yaratılışın 930. yılında ölmüştür), Şit (130-1042), Enoş (235-1140), Keynan (325-1235), Mahalal-El (395-1290), Yared (4601422), Hanoh (622-987), Metüşclah (687-1656), Lamch (874-1651), Nuh (1056-2006). Bkz. Tora, Bereşit, trc. ve düzenleme Moşe Farsi, İstanbul 2002, s. 32, 35.

${ }^{257}$ Metüşelah yüz seksen yedi yaşında iken Lameh (למך) doğmuştu. Bkz. Tekvin, 5/25.

${ }^{258}$ Hanoh alımış beş yaşında iken oğlu Metüşelah (מתושלח) doğmuştu. Bk\%. Tekvin, 5/21.

${ }^{259}$ Yared yüz alımış iki yaşında iken oğlu Hanoh (חנוך) doğmuşıu. Bkz. Tekvin, 5/18.

${ }^{200}$ Mahalal-El alımış beş yaşıncla iken oğlu Yared (ירוך) doğmuştu. Bkะ. Tekvin, 5/15.

${ }^{261}$ Keynan yetmiş yaşında iken oğlu Mahalal-El (מחללאל) doğmuştu. Bkz. Tekvin, 5/12.

${ }^{262}$ Enoş doksan yaşında iken oğlu Keynan (קינן) doğmuşı̨u. Bkz. Tekvin, 5/9.

${ }^{263}$ Şit yüz beş yaşında iken oğlu Enoş (אנוש) doğmuştu. Bkz. Tekvin, 5/6.

${ }^{264} \mathrm{~Hz}$. Âdem'e, Kâbil (Kayin) tarafindan öldürülen oğlu Evel'in (Hâbil) yerine hediye olarak verilen Şit, $\hat{\Lambda} d e m$ yüz otuz yaşında iken dünyaya gelmiştir. "Şit", kelime olarak "Tanrı'nın bahşi" anlamına gelmektedir. Bkz. Tekvin, 4/25. Bilgi kaynağı ehl-i kitap, dolayısıyla Tevrat olduğu anlaşılan İbn Sa'd ve Zübeyrî de Şit için ayn anlama gelen "Hibetullah" ifadesini kullanmışlardır. Bkz. İbn Sa'd, I, 59; Zübeyrî, Nesebü Kureyş, s. 4. 


\section{Nuh Arslantaș}

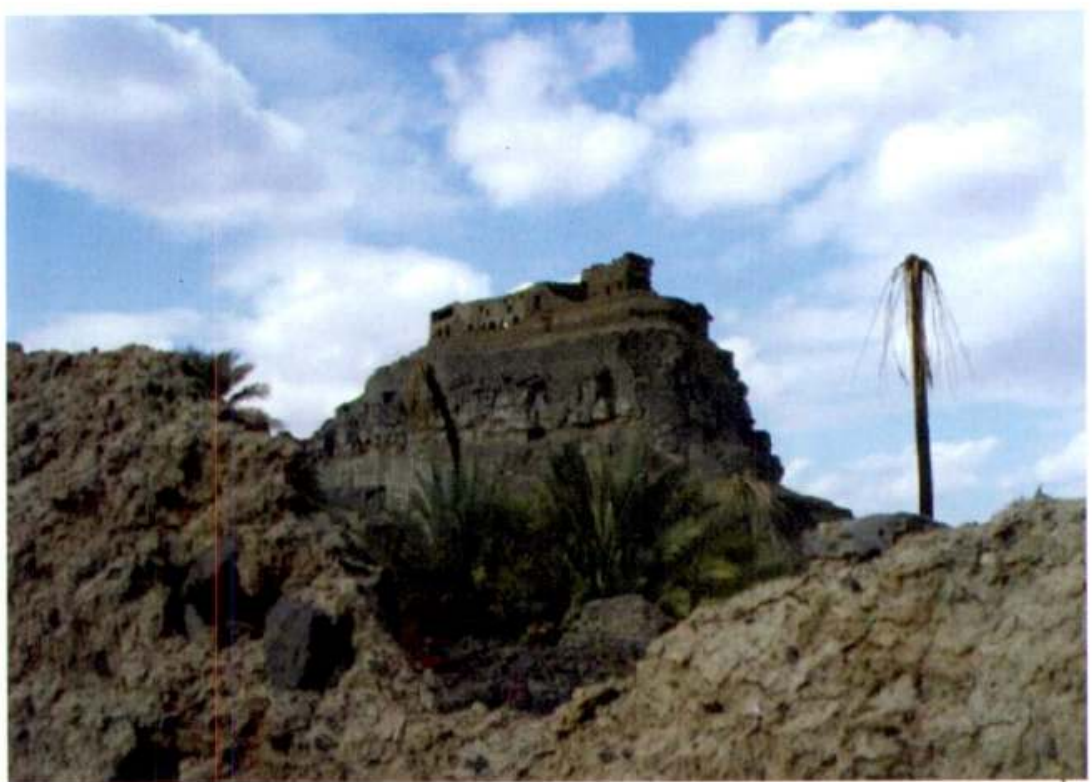

Resim 1 - Merhab Kasrı

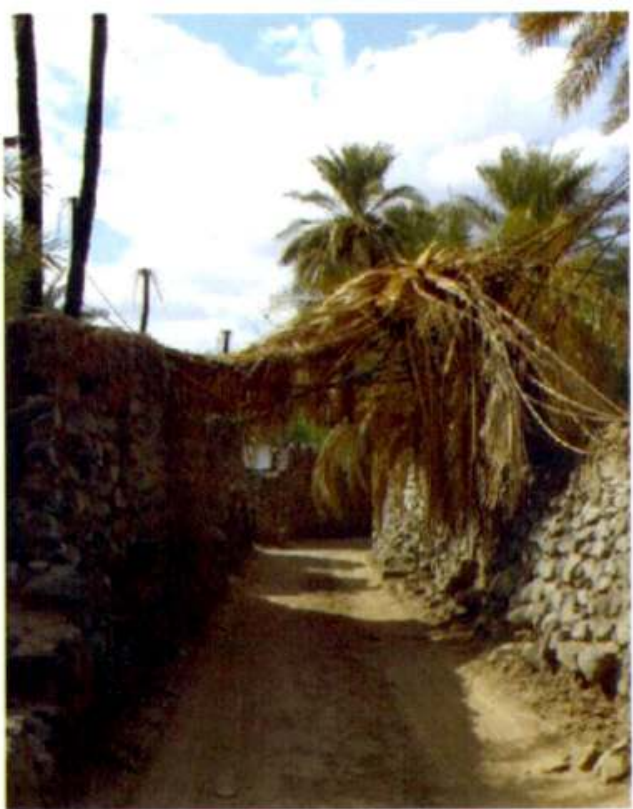

Resim 2 - Merhab Kasrı'na çıkılan yol 


\section{Nuh Arslantaş}

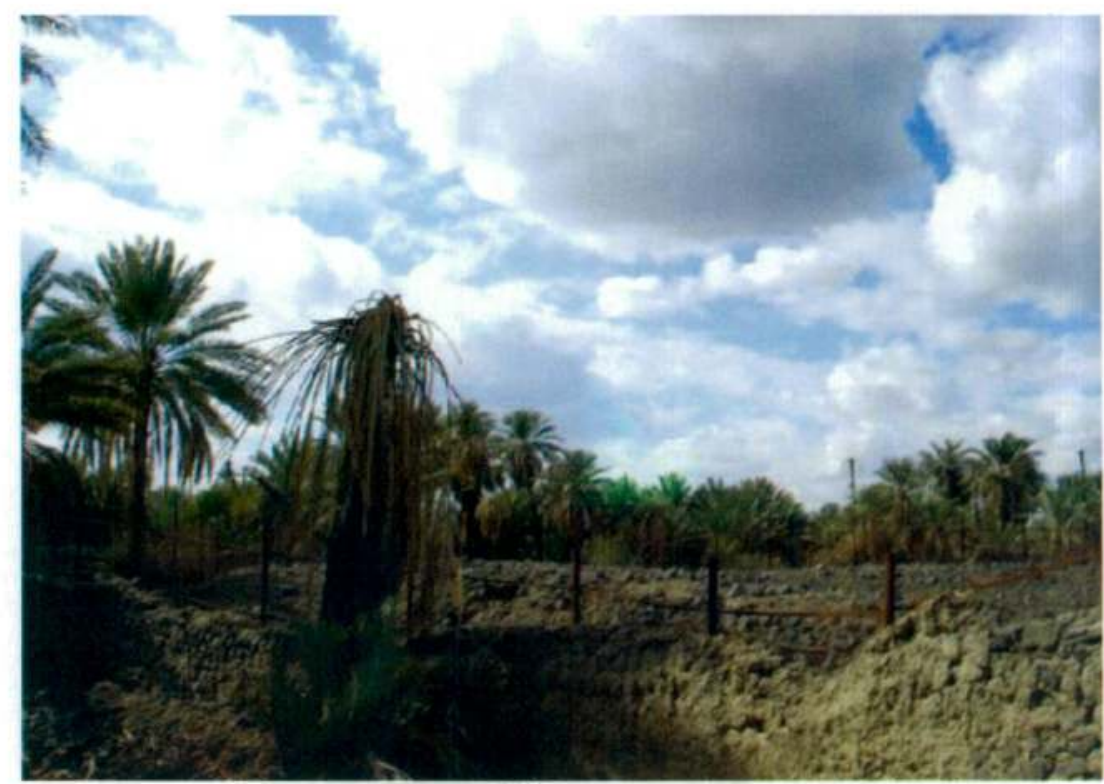

Resim 3 - Hayber'de tarihî Yahudi Mezarlığı.
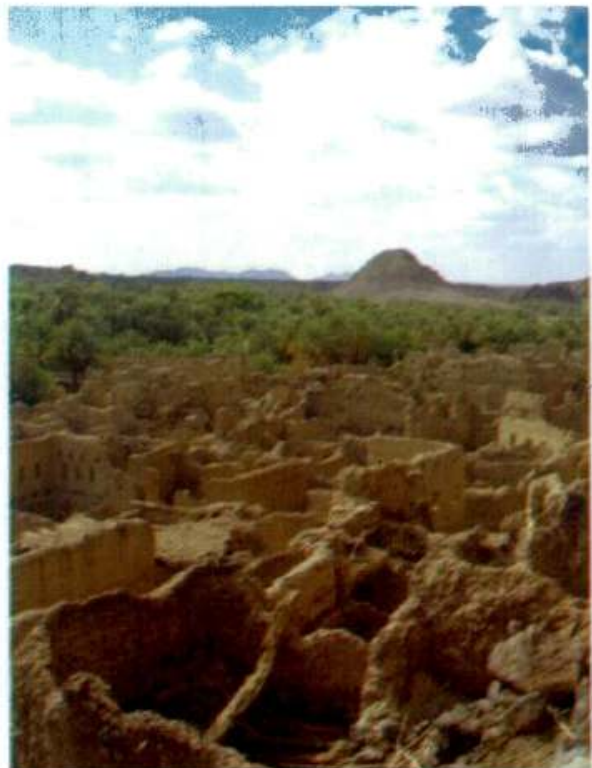

Resinı 4 - Eski Hlayber 'in yukandan görünüșü. 


\section{Nuh Arslantaş}

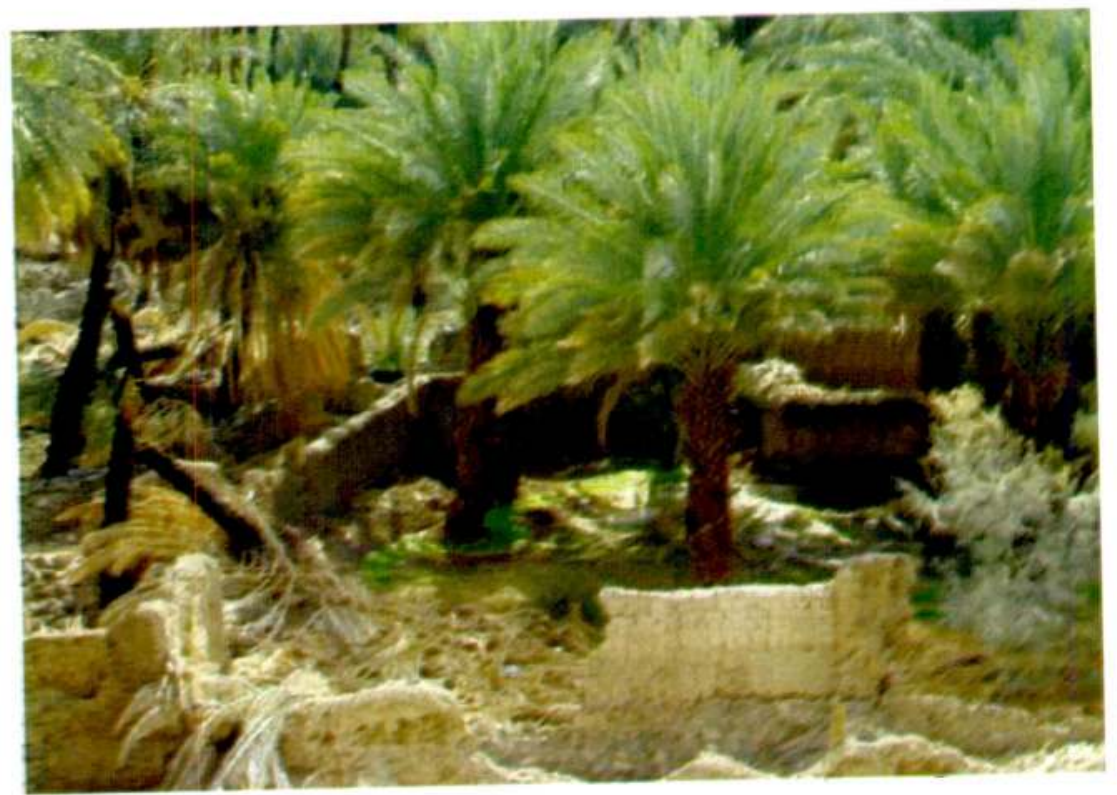

Resim 5 - L:skı Hayder de oulunan huma bahçeicri. 
